\title{
OPTIMAL TRADING STRATEGY DURING BULL AND BEAR MARKETS FOR HONG KONG-LISTED STOCKS
}

\author{
Eddie C. M. HUI ${ }^{1}$, Ka Kwan Kevin CHAN ${ }^{1, *}$ \\ ${ }^{1}$ Department of Building and Real Estate, The Hong Kong Polytechnic University, Hong Kong, China
}

Received 20 October 2016; accepted 20 September 2017

\begin{abstract}
The "buy-and-hold" strategy based on the EMH was believed by many people to be optimal for a long time. However, there has been more criticism on the EMH since the global financial crisis in 2008 . Hence many people attempt to find a trading strategy to beat "buy-and-hold". Moreover, the financial market fluctuates a lot. Sometimes it is in a bull market, but it may be in a bear market during other periods of time, so the optimal strategy during different periods of time may vary and hence switching of strategies may be necessary. In this study, we apply Hui and Chan (2018)'s generalized time-dependent strategy on 12 Hong Kong listed stocks during the whole period of observation and two sub-periods. The results show that when the sub-period December 31, 2004 - December 31, 2008 is chosen, the strategy outperforms "buy-and-hold" by the largest extent. This reflects that the strategy is most effective during adverse market conditions. This study can help investors to apply appropriate trading strategies to earn more profits, and help property practitioners to improve their strategic property management to increase the value of their portfolio.
\end{abstract}

Keywords: trading strategy, Shiryaev-Zhou index, "buy-and-hold", moving-window size, optimal.

\section{Introduction}

Many investors adhere to the "buy-and-hold" strategy supported by the efficient market hypothesis (EMH), which tells that stock prices always fully reflect all available information and therefore is fairly priced, so there is no point to trade. Many studies support the EMH (Malkiel \& Fama, 1970; Malkiel, 2003, 2005; Barber \& Odean, 2000 , etc.). However, due to globalization, there has been a stronger interrelationship between financial markets of different nations recently. Agyei-Ampomah (2011), for instant, find that with the exception of South Africa, African stock markets are segmented from global markets despite recent structural adjustments, providing further evidence on stock market integration in emerging markets. Hatemi-J, Roca, and Al-Shayeb (2014) apply the caseresampling bootstrap method to investigate integration of five internationalized real estate markets with the world market. Except for United Arab Emirates (UAE), all other four markets are found to be integrated with the world market. As a result of stronger interrelationship between markets, financial crises occur more frequently. The global financial crisis in 2008 is the most severe financial crisis since the Great Depression. The financial crisis was caused by the dramatic expansion in subprime mortgage credit which fueled a remarkable boom and bust in the U.S. housing market (Ambrose \& Diop, 2014). The downturn of house prices in the U.S. began in late 2006 (Kim \& Renaud, 2009). The dramatic fall of house prices had massive negative effects on the prices of US subprime mortgagebacked securities. The availability of credit for potential buyers of real estate in the US decreased and borrowers experienced more and more problems to refinance their loans (Basse, Kruse, \& Wegener, 2017). This triggered the subprime crisis in 2007, which turned into the global financial crisis in September 2008 when Lehman Brothers declared bankruptcy.

Many studies show significant evidence of contagion or cointegration across different markets during the global financial crisis. Dooley and Hutchison (2009) find that emerging markets appeared to be somewhat insulated from developments in U.S. financial markets from early 2007 to summer 2008. From that point on, however, emerging markets respond very strongly to the deteriorating situation in the U.S. financial system and real economy. This shows that the impact of the global financial crisis is worldwide. Even emerging markets are not immune. Similar results are found in Hui and Chen

${ }^{*}$ Corresponding author. E-mail: ckkwyc@yahoo.com.hk 
(2012). However, some studies show different results. For example, Bekaert, Ehrmann, Fratzscher, and Mehl (2014) find evidence of contagion from the United States and the global financial sector, but the effects are small. Basse et al. (2017) show that the EMU sovereign debt crisis during 2010-2012 is homemade rather than triggered by the US subprime crunch. Many professionals criticize the EMH during the global financial crisis. Market strategist Jeremy Grantham claims that belief in the EMH caused financial leaders to had a chronic underestimation of the dangers of asset bubbles breaking (New York Times, 2009). Volcker (2011) echoes and states that unjustified faith in rational expectations market efficiencies were parts of the causes of the global financial crisis. If the EMH does not hold, then "buy-and-hold" may not work, so some investors look for alternative trading strategies. If there exists a strategy which outperforms "buy-and-hold", this may provide evidence that the weak form of EMH is false (but more evidence is needed to prove that the EMH is false in general). This is the motivation of our study.

Several studies apply the Shiryaev-Zhou index developed by Shiryaev, Xu, and Zhou (2008) to attempt to find a trading strategy which can beat the "buy-and-hold" strategy. Hui and Yam (2014) apply the Shiryaev-Zhou index to derive a trading strategy which outperforms the "buy-and-hold" strategy in general. The same strategy is applied by Hui, Yam, Wright, and Chan (2014b) and Hui \& Chan (2014) (with minor modifications). All of these three studies use the same moving-window size 130 for their strategies. However, stock prices fluctuate frequently in reality. On a particular day, if the estimator of the Shiryaev-Zhou index is negative (in this case, one has to hold entire cash according to the strategy of Hui and Yam (2014), Hui, Yam, Wright, \& Chan (2014b) and Hui \& Chan (2014)), but the stock price rises, then the strategy would underperform "buy-and-hold" on that day. The optimal moving-window size may not necessarily be 130 . Different stocks/stock indices may have different optimal moving-window sizes, too. In light of this, Hui and Chan (2018) construct a new, generalized time-dependent trading strategy with a variable moving-window size, and apply the generalized strategy on securitized real estate indices and general equity indices of six economies: Hong Kong, Japan, U.S., U.K., France and Germany, during the period December 29, 1995-December 31, 2014. They find that their strategy outperforms the "buy-and-hold" strategy for slightly more than half of the cases. In particular, if the optimal moving-window sizes are used, their strategy beat "buy-and-hold" for most cases. However, they just use a graphical method to roughly analyze the change in optimal moving-window sizes along the timeline. The exact optimal moving-window sizes during different times are not found. Furthermore, they analyze stock indices only, but not the more commonly traded stocks. Different results may be obtained if individual stocks are used.

In this study, we apply Hui and Chan (2018)'s generalized time-dependent trading strategy on 12 Hong Kong listed stocks during the period December 31, 2004 - January $29,2016.6$ of the 12 stocks are property stocks, while the remaining are non-property stocks. We compare the resulting profit of our strategy with that of the "buyand-hold" strategy. For each stock, we find the optimal moving-window size of our strategy for different amounts of transaction costs. To investigate the effect of length of period on the resulting profit of our strategy and the optimal moving-window size, we fix the beginning date of the period to be December 31, 2004, but we set two different ending dates within the whole timeline, and then apply our modified strategy on the 12 stocks again. This study can serve as a reference for investors to construct a better trading strategy to increase their profit. Property practitioners may also follow our strategy to trade real estate securities or even actual real estate.

The paper proceeds as follows: Section 1 presents the literature review. Section 2 describes the formula of the Shiryaev-Zhou index and its statistical estimation. Section 3 describes the data source. Our trading strategies are described in Section 4. Section 5 displays the results. Finally, we draw a conclusion in the last section.

\section{Literature review}

The first to work on portfolio optimization is Markowitz (1952), who introduces the mean-variance modern portfolio theory (MPT). After that, various dynamic investment models are developed, e.g., the Merton portfolio (Samuelson, 1969; Merton, 1971) and the continuous-time Markowitz model (Richardson, 1989). However, they do not result in pure "buy-and-hold". Through investigating the yield structure between broad asset classes and the implications for portfolio allocation decisions and real estate investment, Krystalogianni and Tsolacos (2004) develop a Markov switching strategy which outperform the "buyand-hold" strategy. Cheng et al. (2010) develop a theoretical model to find the optimal holding period for real estate investment. The result shows that higher illiquidity and transaction costs causes longer holding periods, while higher return volatility leads to shorter holding periods, ceteris paribus. Mori and Ziobrowski (2011) compare the performance of pairs trading between the U.S. REIT and general stock markets over the period 1987-2008. After accounting for the effect of the bid-ask bounce between 1993 and 2000, they find that the REIT market outperforms stocks for the strategy. Applying cointegration methods, Gallo, Lockwood, and Zhang (2013) construct globally diversified real estate portfolios which beat the mean-variance optimized portfolio. Hui, Wright, and Yam (2014a) examine 27 international real estate securities indices from 20 countries and regions for calendar effects. The standard approach via linear regression shows that statistically significant calendar anomalies persist. However, the White's Reality Check and Hansen's Superior Predictive Ability tests strongly suggest that the calendar effects are insignificant and hence should not be the basis of investors' trading strategy. 
However, most of the above trading strategies neglect that past stock price trends may affect future trends. In light of this, Deremble, Seager, Potters, and Bouchaud (2014) derive a back-tested strategy: to buy those assets of prices above their five-month averages, and to go short on those below their averages. One should switch positions if prices fell below (or rose above) their five-month averages. Their strategy provides a positive return over all long periods and over each decade in the sample, and also outperforms the "buy-and-hold" strategy as well. The idea in this study is similar to Deremble et al. (2014)'s idea. However, instead of simply taking the five-month averages of stock prices, we make use of the Shiryaev-Zhou index. Applying the probabilistic approach, Shiryaev et al. (2008) derive a "goodness index" $\gamma$ of a stock to find the optimal time to sell the stock, and find that the optimal selling time $t$ is determined by $t=T$ ( $T$ is the end of the period) if $\gamma \geq \frac{1}{2}$, and $t=0$ if $\gamma \leq 0$ (this type of strategies are called "bang-bang" strategies). For the case $0<\gamma<\frac{1}{2}$, Shiryaev et al. (2008) claim that $t=0$, and refer to the PDE approach of Dai, Jin, Zhong, and Zhou (2008). Adopting another probabilistic approach, Du Toit, and Peskir (2008) obtain the same result. Using the techniques in solving the secretary problem, Yam, Yung, and Zhou (2009, 2012, 2012a) resolve the same problem and derive the Shiryaev-Zhou index, which is smaller than the "goodness index" by $1 / 2$.

However, Shiryaev et al. (2008), Du Toit and Peskir (2008) and Yam et al. (2009, 2012, 2012a)'s methods all assume the drift (or return) and volatility to be constants. Yet, in reality, the market fundamentals are always varying. Therefore, it is more reasonable to assume that the parameters vary in time. Wong, Wright, Yam, and Yung (2012) develop a dynamic bang-bang strategy allowing for parameters of the return distribution to vary over time. Provided that the parameter $\lambda$ is estimated using recent returns (in this way, Wong et al. (2012)'s method is similar to Deremble et al. (2014)'s), their strategy beat "buy-andhold" on the CRSP, FTSE 100 and Hang Seng indices. The sign of $\lambda$ is the same as that of the Shiryaev-Zhou index (Wong et al., 2012) and determines the optimal buying/ selling time of a stock. This provides the theoretical and conceptual framework of our study.

Hui, Yam, and Chen (2012) applies the Shiryaev-Zhou index several real estate stocks listed in Hong Kong. Only the latest selling dates of each stock are listed, but the resulting profit is not computed. Hui and Yam (2014) derive a trading strategy from the Shiryaev-Zhou index, and test it on four European and North American securitized real estate indices. Their strategy outperforms the "buy-and-hold" strategy in general. Hui et al. (2014b) apply the same strategy on six Asian securitized real estate indices and show that the strategy also generally beats the "buy-and-hold" strategy. However, Hui and Chan (2014) obtain mixed results on Hong Kong listed stocks: the strategy still outperforms "buy-and-hold" in overall for property stocks, but underperforms "buy-and-hold" for most non-property stocks, in particular when transaction costs exist.

However, Hui and Yam (2014), Hui et al. (2014b) and Hui and Chan (2014) all use a fixed moving-window size $(n=130)$ to calculate the estimator of the Shiryaev-Zhou index and hence derive their trading strategy. Hence the resulting profit is fixed if transaction costs remain constant. In reality, the stock price is always fluctuating. Therefore, if a different moving-window size is used, the estimator of the Shiryaev-Zhou index and thus the resulting profit derived by the strategy may change. Hui and Chan (2018) construct a new time-dependent trading strategy with variable moving-window size, and applied the generalized strategy on 12 stock indices (6 securitized real estate indices and 6 general equity indices). They work out the optimal moving-window size of their strategy for each stock index. However, they do not analyze how the change in length of timeline affects the resulting profit of their strategy and the optimal moving-window size. In order to fill in this gap, in this study, we not only apply Hui and Chan (2018)'s strategy on 12 Hong Kong listed stocks, but also change the ending date of the timeline and calculate the resulting profit of our strategy among different ending dates of the period.

\section{The Shiryaev-Zhou index and its statistical estimation}

The Shiryaev-Zhou index is derived from the problem of minimizing the time between the selling and maximum prices of the stock:

$$
V^{*}=\max _{0 \leq \tau \leq T} \mathrm{E}\left[\frac{S_{\tau}}{S_{T}}\right],
$$

where: $T>0$, E denotes expectation, and $S_{T}=\max _{0 \leq s \leq t} S_{s}$ is the maximum stock price during the period $[0, t]$.

The solution to problem (2.1) is $V^{*}=T$ when $\gamma \geq \frac{1}{2}$, and $V^{*}=0$ otherwise, where $\gamma$ is the "goodness index" of the stock (Shiryaev et al., 2008).

Problem (2.1) is resolved by Yam et al. $(2009,2012$, 2012a), who find that $V^{*}=T$ when $\mu \geq 0$, and $V^{*}=0$ otherwise, where $\mu$ is the Shiryaev-Zhou index defined by Yam et al. (2009, 2012, 2012a), Hui et al. (2012, 2014b), Hui and Yam (2014), Hui and Chan (2014), Hui and Chan (2018):

$$
\mu=\left(\alpha-0.5 \sigma^{2}\right) / \sigma^{2}=\alpha / \sigma^{2}-0.5,
$$

where: $\alpha, \sigma$ are the annual growth rate (or drift) and the annual volatility of the stock respectively ( $\alpha, \sigma$ are constants).

The two trading strategies derived above are the same because $\gamma=\mu+\frac{1}{2}$.

In reality, the drift $\alpha$ and volatility $\sigma$ are always fluctuating. Their exact values are normally not known. Hence the moving-window approach is adopted (Hui et al., 2014b, Hui \& Chan, 2018). 
The continuously compounded daily return of a stock on day $i, r_{i}(i \geq 2)$ is given by:

$$
r_{i}=\log \left(\frac{S_{i}}{S_{i-1}}\right),
$$

where: $S_{i}$ is the stock's closing price on day $i$.

We use the sample mean to estimate the average daily return of the stock on day $i(i>n)$ :

$$
\overline{r_{i}}(n)=\frac{1}{n} \sum_{j=1}^{n} r_{i-n+j} .
$$

Assuming 250 trading days in a year, the estimator of $\alpha$ on day $i(i>n)$ is:

$$
\hat{\alpha}_{i}(n)=250 \bar{r}_{i}(n) \text {. }
$$

We use the sample variance to estimate the daily variance of the stock on day $i(i>n)$ :

$$
s_{i}^{2}(n)=\frac{1}{n-1} \sum_{j=1}^{n}\left(r_{i-n+j}-\bar{r}_{j}(n)\right)^{2} .
$$

Therefore, the estimator of the variance $\sigma^{2}$ on day $i$ $(i>n)$ is:

$$
\hat{\sigma}_{i}^{2}(n)=250 s_{i}^{2}(n) .
$$

Thus we derive the estimator of the Shiryaev-Zhou in$\operatorname{dex} \mu$ on day $i(i>n)$ :

$$
\hat{\mu}_{i}(n)=\frac{\hat{\alpha}_{i}(n)-0.5 \hat{\sigma}_{i}^{2}(n)}{\hat{\sigma}_{i}^{2}(n)}=\frac{\hat{\alpha}_{i}(n)}{\hat{\sigma}_{i}^{2}(n)}-0.5 .
$$

\section{Data}

The whole period of observation is December 31, 2004-January 29, 2016, a total of 2735 observations. Since the largest moving-window size we choose is 240 , the calculation of the estimated value of Shiryaev-Zhou index $\hat{\mu}_{i}(n)$ on day $i$ using the moving-window size $n=240$ requires the stock price on day $i-240$ to be known. Hence we trace back the timeline by 240 days, i.e. back to January 14, 2004.

Next we select the 12 stocks, which are divided into 6 property stocks and 6 non-property stocks. All of the 12 stocks are currently constituent stocks of Hang Seng Index (HSI), and satisfy the following criteria:

1. All stocks must be listed on Hong Kong Stock Exchange (HKSE) during the whole period December 31, 2004 - January 29, 2016.

2. All stocks must be constituent stocks of Hang Seng Index (HSI) for at least 5 years and 7 months during the period of observation.

3. Each of the 6 property stocks must be a constituent stock of Hang Seng Property (HSP) Index for at least 5 years and 7 months during the period of observation.

4. 6 of the 12 stocks are China enterprises, while the remaining 6 stocks are non-China enterprises.

The 12 stocks selected are shown in the Table 1 .

Only constituent stocks of HSI are chosen because they are the most frequently traded stocks in Hong Kong. They have much larger market values and transaction volumes than other stocks. Since December 12, 2012, HSI has a total of 50 constituent stocks. From Table 1, the 12 stocks make up of $33 \%$ of the total share of HSI, so they are quite representative. Since China enterprises have an increasing impact on Hong Kong's financial market, half of the selected stocks are China enterprises. Thus we can compare the performance of our strategy on stocks of China enterprises with that on stocks of non-China enterprises.

\section{Our trading strategies}

Here we apply the estimator $\hat{\mu}_{i}(n)$ of the Shiryaev-Zhou index to construct a trading strategy. The following two assumptions are made:

Table 1 . The 12 stocks we choose

\begin{tabular}{|c|l|l|l|l|c|}
\hline $\begin{array}{c}\text { Stock } \\
\text { no. }\end{array}$ & \multicolumn{1}{|c|}{ Company name } & $\begin{array}{c}\text { Nature of } \\
\text { business }\end{array}$ & $\begin{array}{c}\text { Origin of } \\
\text { business }\end{array}$ & $\begin{array}{c}\text { Period as a constituent stock of } \\
\text { HSI }\end{array}$ & $\begin{array}{c}\text { HSI (as of } \\
\text { December } \\
24,2015)\end{array}$ \\
\hline 5 & HSBC Holdings & Non-property & Non-China & Whole period & $10.00 \%$ \\
\hline 12 & Henderson Land & Property & Non-China & Whole period & $0.67 \%$ \\
\hline 16 & Sun Hung Kai Properties & Property & Non-China & Whole period & $1.99 \%$ \\
\hline 83 & Sino Land & Property & Non-China & Whole period & $0.52 \%$ \\
\hline 101 & Hang Lung Properties & Property & Non-China & Whole period & $0.49 \%$ \\
\hline 388 & HKEx & Non-property & Non-China & September 11,2006 onwards & $3.13 \%$ \\
\hline 688 & China Overseas & Property & China & December 10,2007 onwards & $1.42 \%$ \\
\hline 857 & PetroChina & Non-property & China & December 10, 2007 onwards & $1.72 \%$ \\
\hline 883 & China National Offshore Oil & Non-property & China & Whole period & $2.31 \%$ \\
\hline 941 & China Mobile & Non-property & China & Whole period & $8.18 \%$ \\
\hline 1109 & China Resources Land & Property & China & March 8,2010 onwards & $0.81 \%$ \\
\hline 2628 & China Life Insurance Company & Non-property & China & March 12,2007 onwards & $2.11 \%$ \\
\hline
\end{tabular}


(1) The transaction price (buying and selling price) of a stock index on a particular day is its closing price on that day.

(2) The amount of cash held at time $t=0$ is adequate to cover all transactions during the period. 2018):

Our trading strategy is as follows (Hui \& Chan, 2014a,

1. On day 1 , if $\hat{\mu}_{1}(n) \geq 0$, buy one unit of the stock. Otherwise, take no action.

2. From day 2 to the second last day of the period, trade the stock according to Table 2 .

Table 2. Our trading strategy from Day 2 to the second last day

\begin{tabular}{|c|c|l|}
\hline$\hat{\mu}_{i-1}(n)$ & $\hat{\mu}_{i}(n)$ & \multicolumn{1}{|c|}{ Action } \\
\hline$\geq 0$ & $\geq 0$ & No action (keep holding one unit of the stock) \\
\hline$\geq 0$ & $<0$ & Sell the entire one unit of the stock we hold \\
\hline$<0$ & $\geq 0$ & Buy one unit of the stock \\
\hline$<0$ & $<0$ & No action (keep holding entire cash) \\
\hline
\end{tabular}

3. On the final day of the period, sell the entire one unit of the stock if one is still holding the one unit of the stock. Otherwise, do not take any action.

The above trading strategy is called Strategy 1.

Since the profit of Strategy 1 depends on the sign of $\hat{\mu}_{i}(n)$, which is a function of the moving-window size $n$, the profit of Strategy 1 also depends on $n$. Hence Strategy 1 is a time-dependent strategy.

From Table 2, Strategy 1 can be simplified as follows: on day $i(i \geq 2)$, hold one unit of the stock if $\hat{\mu}_{i-1}(n) \geq 0$ (the periods of which $\hat{\mu}_{i-1}(n) \geq 0$ are called "holding periods"). Otherwise, hold entire cash (the periods of which $\hat{\mu}_{i-1}(n)<0$ are called "non-holding periods"). Hence without transaction costs, the profit on day $i$ is the same for both "buy-and-hold" and Strategy 1 during the "holding periods". The stock price movements during the "non-holding periods" contribute to the difference between profits of "buy-and-hold" and Strategy 1: on day $i$, if $\hat{\mu}_{i-1}(n)<0$, but the stock price rises, then "buy-and-hold" beats Strategy 1 . On the other hand, if $\hat{\mu}_{i-1}(n)<0$ and the stock price falls, then Strategy 1 outperforms "buy-andhold". Summing up the differences between the profits of Strategy 1 and "buy-and-hold" during the "non-holding periods", we can see whether Strategy 1 outperforms "buyand-hold" or not.

We consider the following four cases:

(1) No transaction costs.

(2) $0.1 \%$ transaction costs.

(3) $0.2 \%$ transaction costs.

(4) $0.35 \%$ transaction costs.

The first three cases are same as those in Hui and Chan (2014a, 2018). The final case resembles the actual level of transaction costs in Hong Kong, which consist mainly of stamp duty, which is $0.1 \%$ of the transaction price, and commission fee. The amount of commission fee varies between banks. We set the commission fee to be $0.25 \%$ of the transaction price as this level of commission fee is adopted by most banks in Hong Kong, including HSBC and Hang Seng Bank. With other types of transaction costs negligible, this makes the transaction costs to be $0.35 \%$ of the transaction price.

Since our period of observation is December 31, 2004 - January 29, 2016, the "buy-and-hold" strategy in this study refers to buying one unit of the stock on December 31, 2004, and selling the entire one unit of the stock on January 29, 2016.

We select the following 6 moving-window sizes $n$ as in Hui and Chan (2018): 40, 80, 120, 160, 200, 240, and test Strategy 1 for these 6 moving window sizes on each of the 12 stocks for zero, $0.1 \%, 0.2 \%$ and $0.35 \%$ transaction costs. We compare the resulting profit of Strategy 1 with that of the "buy-and-hold" strategy. Then, for each stock and each case of amount of transaction costs $(0 \%$, $0.1 \%, 0.2 \%$ and $0.35 \%$ ), we test Strategy 1 for all cases of moving-window sizes $n$ under the constraint $n \leq 240$ (without this constraint, we have to test infinite number of moving-window sizes, which is impossible). We find out the moving-window size which gives the maximum profit for Strategy 1, i.e. the optimal moving-window size. The corresponding strategy is called the optimal strategy. Furthermore, assuming no transaction costs and using the 6 selected moving-window sizes $(40,80,120,160,200,240)$, we draw a graph to track Strategy 1 and "buy-and-hold" along the whole period of observation to compare the difference between the profits of Strategy 1 and "buy-andhold" during different times in the period.

However, the graphical method can only give a rough sketch of the relationship between length of period and the resulting profit of Strategy 1. To investigate how the length of period affects the profit of Strategy 1 and the optimal window size, we fix the beginning date of the period to be December 31, 2004, but we set two new ending dates of the period: December 31, 2008 and December 31, 2012. The corresponding strategies are called Strategy 2 and Strategy 3 respectively. We apply Strategies 2 and 3 on the 12 stocks, and compare the resulting profits with that of the "buy-and-hold" strategy. We also calculate the optimal moving-window size for each stock and each case of amount of transaction costs. We compare the results of Strategies 2 and 3 with that of Strategy 1.

\section{The results}

\subsection{The optimal moving-window size of Strategy 1}

We apply Strategy 1 and the "buy-and-hold" strategy on the 12 stocks selected in Section 3 during the period December 31, 2004 - January 29, 2016. We select the 6 different moving-window sizes $n$ for Strategy 1 described in Section 4: 40, $80,120,160,200,240$, and consider all the 4 cases of different amounts of transaction costs mentioned in Section 4 ( $0 \%, 0.1 \%, 0.2 \%$ and $0.35 \%)$. We determine which movingwindow size $n$ yields the maximum profit for Strategy 1 for a particular amount of transaction costs for each stock. The results are shown in the Table 3 (note that for Strategy 1, the base for calculating the percentage profit is the initial cost). 
Table 3. Comparison between the profits of Strategy 1 and "buy-and-hold" (the red entries indicate that Strategy 1 beats "buy-andhold", while the numbers in the brackets indicate the percentage profits)

\begin{tabular}{|c|c|c|c|c|c|c|c|}
\hline Moving-window size & 40 & 80 & 120 & 160 & 200 & 240 & buy-and-hold \\
\hline \multicolumn{8}{|c|}{ Stock no. 5} \\
\hline No transaction costs & $\begin{array}{c}-18.42 \\
(-14.95 \%)\end{array}$ & $\begin{array}{c}2.48 \\
(2.01 \%)\end{array}$ & $\begin{array}{c}-39.35 \\
(-31.95 \%)\end{array}$ & $\begin{array}{c}-22.13 \\
(-17.97 \%)\end{array}$ & $\begin{array}{c}-9.08 \\
(-7.38 \%)\end{array}$ & $\begin{array}{c}-36.09 \\
(-29.30 \%)\end{array}$ & $\begin{array}{c}-68.66 \\
(-55.75 \%)\end{array}$ \\
\hline $0.1 \%$ transaction costs & $\begin{array}{c}-36.67 \\
(-29.75 \%)\end{array}$ & $\begin{array}{c}-9.97 \\
(-8.09 \%)\end{array}$ & $\begin{array}{c}-53.36 \\
(-43.28 \%)\end{array}$ & $\begin{array}{c}-30.91 \\
(-25.08 \%)\end{array}$ & $\begin{array}{c}-14.86 \\
(-12.05 \%)\end{array}$ & $\begin{array}{c}-42.52 \\
(-34.49 \%)\end{array}$ & $\begin{array}{c}-68.84 \\
(-55.84 \%)\end{array}$ \\
\hline $0.2 \%$ transaction costs & $\begin{array}{c}-54.92 \\
(-44.51 \%)\end{array}$ & $\begin{array}{c}-22.42 \\
(-18.17 \%)\end{array}$ & $\begin{array}{c}-67.37 \\
(-54.59 \%)\end{array}$ & $\begin{array}{c}-39.69 \\
(-32.16 \%)\end{array}$ & $\begin{array}{c}-20.63 \\
(-16.72 \%)\end{array}$ & $\begin{array}{c}-48.94 \\
(-39.66 \%)\end{array}$ & $\begin{array}{c}-69.01 \\
(-55.92 \%)\end{array}$ \\
\hline $0.35 \%$ transaction costs & $\begin{array}{c}-82.30 \\
(-66.60 \%)\end{array}$ & $\begin{array}{c}-41.09 \\
(-33.25 \%)\end{array}$ & $\begin{array}{c}-88.39 \\
(-71.52 \%)\end{array}$ & $\begin{array}{c}-52.86 \\
(-42.77 \%)\end{array}$ & $\begin{array}{c}-29.29 \\
(-23.70 \%)\end{array}$ & $\begin{array}{c}-58.58 \\
(-47.40 \%)\end{array}$ & $\begin{array}{c}-69.28 \\
(-56.06 \%)\end{array}$ \\
\hline $\begin{array}{l}\text { No. of times of buying (or selling) } \\
\text { the stock for Strategy } 1\end{array}$ & 96 & 67 & 70 & 46 & 31 & 34 & \\
\hline \multicolumn{8}{|c|}{ Stock no. 12} \\
\hline No transaction costs & $\begin{array}{c}19.95 \\
(65.71 \%)\end{array}$ & $\begin{array}{c}29.73 \\
(97.95 \%)\end{array}$ & $\begin{array}{c}16.13 \\
(53.13 \%)\end{array}$ & $\begin{array}{c}17.05 \\
(56.19 \%)\end{array}$ & $\begin{array}{c}-6.06 \\
(-19.96 \%)\end{array}$ & $\begin{array}{c}-6.27 \\
(-23.72 \%)\end{array}$ & $\begin{array}{c}11.65 \\
(38.37 \%)\end{array}$ \\
\hline $0.1 \%$ transaction costs & $\begin{array}{c}14.07 \\
(46.31 \%)\end{array}$ & $\begin{array}{c}25.43 \\
(83.71 \%)\end{array}$ & $\begin{array}{c}12.60 \\
(41.47 \%)\end{array}$ & $\begin{array}{c}14.05 \\
(46.24 \%) \\
\end{array}$ & $\begin{array}{c}-10.41 \\
(-34.26 \%)\end{array}$ & $\begin{array}{c}-9.67 \\
(-36.54 \%)\end{array}$ & $\begin{array}{c}11.57 \\
(38.10 \%)\end{array}$ \\
\hline $0.2 \%$ transaction costs & $\begin{array}{c}8.20 \\
(26.95 \%) \\
\end{array}$ & $\begin{array}{c}21.14 \\
(69.50 \%) \\
\end{array}$ & $\begin{array}{c}9.07 \\
(29.83 \%)\end{array}$ & $\begin{array}{c}11.04 \\
(36.31 \%)\end{array}$ & $\begin{array}{c}-14.76 \\
(-48.54 \%) \\
\end{array}$ & $\begin{array}{c}-13.07 \\
(-49.33 \%) \\
\end{array}$ & $\begin{array}{c}11.50 \\
(37.82 \%)\end{array}$ \\
\hline $0.35 \%$ transaction costs & $\begin{array}{c}-0.61 \\
(-2.01 \%)\end{array}$ & $\begin{array}{c}14.69 \\
(48.23 \%)\end{array}$ & $\begin{array}{c}3.78 \\
(12.41 \%)\end{array}$ & $\begin{array}{c}6.53 \\
(21.45 \%)\end{array}$ & $\begin{array}{c}-21.29 \\
(-69.90 \%)\end{array}$ & $\begin{array}{c}-18.17 \\
(-68.48 \%)\end{array}$ & $\begin{array}{c}11.39 \\
(37.41 \%)\end{array}$ \\
\hline $\begin{array}{l}\text { No. of times of buying (or selling) } \\
\text { the stock for Strategy } 1\end{array}$ & 77 & 58 & 50 & 43 & 57 & 45 & \\
\hline \multicolumn{8}{|c|}{ Stock no. 16} \\
\hline No transaction costs & $\begin{array}{c}50.05 \\
(64.37 \%)\end{array}$ & $\begin{array}{c}108.00 \\
(138.91 \%)\end{array}$ & $\begin{array}{c}30.40 \\
(39.10 \%)\end{array}$ & $\begin{array}{c}24.55 \\
(31.58 \%)\end{array}$ & $\begin{array}{c}2.95 \\
(3.79 \%)\end{array}$ & $\begin{array}{c}3.30 \\
(4.24 \%)\end{array}$ & $\begin{array}{c}6.05 \\
(7.78 \%)\end{array}$ \\
\hline $0.1 \%$ transaction costs & $\begin{array}{c}31.77 \\
(40.82 \%)\end{array}$ & $\begin{array}{c}98.26 \\
(126.25 \%)\end{array}$ & $\begin{array}{c}19.35 \\
(24.86 \%)\end{array}$ & $\begin{array}{c}15.03 \\
(19.31 \%)\end{array}$ & $\begin{array}{c}-4.69 \\
(-6.03 \%)\end{array}$ & $\begin{array}{c}-4.34 \\
(-5.58 \%)\end{array}$ & $\begin{array}{c}5.89 \\
(7.57 \%)\end{array}$ \\
\hline $0.2 \%$ transaction costs & $\begin{array}{c}13.48 \\
(17.31 \%)\end{array}$ & $\begin{array}{c}88.52 \\
(113.62 \%)\end{array}$ & $\begin{array}{c}8.29 \\
(10.65 \%)\end{array}$ & $\begin{array}{c}5.51 \\
(7.08 \%)\end{array}$ & $\begin{array}{c}-12.34 \\
(-15.84 \%)\end{array}$ & $\begin{array}{c}-11.98 \\
(-15.38 \%)\end{array}$ & $\begin{array}{c}5.73 \\
(7.35 \%)\end{array}$ \\
\hline $0.35 \%$ transaction costs & $\begin{array}{c}-13.94 \\
(-17.87 \%)\end{array}$ & $\begin{array}{c}73.91 \\
(94.73 \%) \\
\end{array}$ & $\begin{array}{c}-8.28 \\
(-10.62 \%)\end{array}$ & $\begin{array}{c}-8.76 \\
(-11.23 \%) \\
\end{array}$ & $\begin{array}{c}-23.80 \\
(-30.51 \%) \\
\end{array}$ & $\begin{array}{c}-23.45 \\
(-30.05 \%)\end{array}$ & $\begin{array}{c}5.48 \\
(7.03 \%)\end{array}$ \\
\hline $\begin{array}{l}\text { No. of times of buying (or selling) } \\
\text { the stock for Strategy } 1\end{array}$ & 88 & 49 & 57 & 48 & 39 & 37 & \\
\hline \multicolumn{8}{|c|}{ Stock no. 83} \\
\hline No transaction costs & $\begin{array}{c}2.41 \\
(34.58 \%)\end{array}$ & $\begin{array}{c}7.33 \\
(105.38 \%)\end{array}$ & $\begin{array}{c}10.00 \\
(143.82 \%)\end{array}$ & $\begin{array}{c}1.70 \\
(24.44 \%)\end{array}$ & $\begin{array}{c}2.11 \\
(30.35 \%)\end{array}$ & $\begin{array}{c}-1.74 \\
(-24.96 \%)\end{array}$ & $\begin{array}{c}2.93 \\
(42.06 \%)\end{array}$ \\
\hline $0.1 \%$ transaction costs & $\begin{array}{c}0.26 \\
(3.73 \%)\end{array}$ & $\begin{array}{c}5.49 \\
(78.81 \%)\end{array}$ & $\begin{array}{c}9.03 \\
(129.68 \%)\end{array}$ & $\begin{array}{c}0.40 \\
(5.71 \%)\end{array}$ & $\begin{array}{c}0.89 \\
(12.85 \%)\end{array}$ & $\begin{array}{c}-2.82 \\
(-40.45 \%)\end{array}$ & $\begin{array}{c}2.91 \\
(41.77 \%)\end{array}$ \\
\hline $0.2 \%$ transaction costs & $\begin{array}{c}-1.89 \\
(-27.06 \%)\end{array}$ & $\begin{array}{c}3.64 \\
(52.29 \%) \\
\end{array}$ & $\begin{array}{c}8.05 \\
(115.57 \%)\end{array}$ & $\begin{array}{c}-0.90 \\
(-12.98 \%)\end{array}$ & $\begin{array}{c}-0.32 \\
(-4.62 \%)\end{array}$ & $\begin{array}{c}-3.90 \\
(-55.91 \%)\end{array}$ & $\begin{array}{c}2.89 \\
(41.49 \%) \\
\end{array}$ \\
\hline $0.35 \%$ transaction costs & $\begin{array}{c}-5.10 \\
(-73.13 \%)\end{array}$ & $\begin{array}{c}0.88 \\
(12.61 \%)\end{array}$ & $\begin{array}{c}6.59 \\
(94.45 \%)\end{array}$ & $\begin{array}{c}-2.86 \\
(-40.95 \%)\end{array}$ & $\begin{array}{c}-2.15 \\
(-30.76 \%)\end{array}$ & $\begin{array}{c}-5.52 \\
(-79.03 \%)\end{array}$ & $\begin{array}{c}2.87 \\
(41.07 \%)\end{array}$ \\
\hline $\begin{array}{l}\text { No. of times of buying (or selling) } \\
\text { the stock for Strategy } 1\end{array}$ & 87 & 76 & 40 & 49 & 45 & 39 & \\
\hline \multicolumn{8}{|c|}{ Stock no. 101} \\
\hline No transaction costs & $\begin{array}{c}-16.96 \\
(-141.33 \%)\end{array}$ & $\begin{array}{c}8.80 \\
(73.33 \%)\end{array}$ & $\begin{array}{c}13.89 \\
(115.75 \%)\end{array}$ & $\begin{array}{c}-1.88 \\
(-15.67 \%)\end{array}$ & $\begin{array}{c}8.55 \\
(71.25 \%) \\
\end{array}$ & $\begin{array}{c}4.10 \\
(34.17 \%)\end{array}$ & $\begin{array}{c}2.26 \\
(18.83 \%)\end{array}$ \\
\hline $0.1 \%$ transaction costs & $\begin{array}{c}-22.24 \\
(-185.18 \%)\end{array}$ & $\begin{array}{c}5.22 \\
(43.45 \%) \\
\end{array}$ & $\begin{array}{c}11.73 \\
(97.64 \%)\end{array}$ & $\begin{array}{c}-4.28 \\
(-35.62 \%)\end{array}$ & $\begin{array}{c}6.31 \\
(52.56 \%)\end{array}$ & $\begin{array}{c}2.13 \\
(17.69 \%)\end{array}$ & $\begin{array}{c}2.23 \\
(18.60 \%)\end{array}$ \\
\hline $0.2 \%$ transaction costs & $\begin{array}{c}-27.53 \\
(-228.93 \%)\end{array}$ & $\begin{array}{c}1.64 \\
(13.63 \%)\end{array}$ & $\begin{array}{c}9.57 \\
(79.56 \%)\end{array}$ & $\begin{array}{c}-6.68 \\
(-55.54 \%)\end{array}$ & $\begin{array}{c}4.08 \\
(33.91 \%)\end{array}$ & $\begin{array}{c}0.15 \\
(1.25 \%)\end{array}$ & $\begin{array}{c}2.21 \\
(18.36 \%)\end{array}$ \\
\hline $0.35 \%$ transaction costs & $\begin{array}{c}-35.45 \\
(-294.41 \%)\end{array}$ & $\begin{array}{c}-3.73 \\
(-30.99 \%)\end{array}$ & $\begin{array}{c}6.32 \\
(52.52 \%)\end{array}$ & $\begin{array}{c}-10.28 \\
(-85.34 \%)\end{array}$ & $\begin{array}{c}0.72 \\
(6.01 \%)\end{array}$ & $\begin{array}{c}-2.81 \\
(-23.35 \%)\end{array}$ & $\begin{array}{c}2.17 \\
(18.00 \%)\end{array}$ \\
\hline $\begin{array}{l}\text { No. of times of buying (or selling) } \\
\text { the stock for Strategy } 1\end{array}$ & 109 & 75 & 48 & 49 & 49 & 42 & \\
\hline \multicolumn{8}{|c|}{ Stock no. 388} \\
\hline No transaction costs & $\begin{array}{c}371.25 \\
(1784.86 \%)\end{array}$ & $\begin{array}{c}307.50 \\
(1478.37 \%)\end{array}$ & $\begin{array}{c}224.00 \\
(1076.92 \%)\end{array}$ & $\begin{array}{c}197.70 \\
(950.48 \%)\end{array}$ & $\begin{array}{c}136.60 \\
(700.51 \%)\end{array}$ & $\begin{array}{c}97.75 \\
(469.95 \%)\end{array}$ & $\begin{array}{c}149.50 \\
(718.75 \%)\end{array}$ \\
\hline $0.1 \%$ transaction costs & $\begin{array}{c}353.44 \\
(1697.54 \%)\end{array}$ & $\begin{array}{c}299.55 \\
(1438.69 \%)\end{array}$ & $\begin{array}{c}215.39 \\
(1034.49 \%)\end{array}$ & $\begin{array}{c}192.79 \\
(925.95 \%)\end{array}$ & $\begin{array}{c}130.96 \\
(670.93 \%)\end{array}$ & $\begin{array}{c}90.43 \\
(434.30 \%)\end{array}$ & $\begin{array}{c}149.31 \\
(717.11 \%)\end{array}$ \\
\hline $0.2 \%$ transaction costs & $\begin{array}{c}335.63 \\
(1610.39 \%)\end{array}$ & $\begin{array}{c}291.59 \\
(1399.09 \%)\end{array}$ & $\begin{array}{c}206.78 \\
(992.13 \%) \\
\end{array}$ & $\begin{array}{c}187.88 \\
(901.47 \%)\end{array}$ & $\begin{array}{c}125.33 \\
(641.41 \%)\end{array}$ & $\begin{array}{c}83.10 \\
(398.73 \%)\end{array}$ & $\begin{array}{c}149.12 \\
(715.48 \%)\end{array}$ \\
\hline $0.35 \%$ transaction costs & $\begin{array}{c}308.92 \\
(1480.00 \%)\end{array}$ & $\begin{array}{c}279.66 \\
(1339.84 \%)\end{array}$ & $\begin{array}{c}193.86 \\
(928.76 \%)\end{array}$ & $\begin{array}{c}180.52 \\
(864.85 \%)\end{array}$ & $\begin{array}{c}116.87 \\
(597.24 \%)\end{array}$ & $\begin{array}{c}72.11 \\
(345.49 \%)\end{array}$ & $\begin{array}{c}148.83 \\
(713.04 \%)\end{array}$ \\
\hline $\begin{array}{l}\text { No. of times of buying (or selling) } \\
\text { the stock for Strategy } 1\end{array}$ & 65 & 32 & 32 & 18 & 21 & 27 & \\
\hline
\end{tabular}


End of Table 3

\begin{tabular}{|c|c|c|c|c|c|c|c|}
\hline Moving-window size & 40 & 80 & 120 & 160 & 200 & 240 & buy-and-hold \\
\hline \multicolumn{8}{|c|}{ Stock no. 688} \\
\hline No transaction costs & $\begin{array}{c}5.34 \\
(297.60 \%)\end{array}$ & $\begin{array}{c}5.16 \\
(287.62 \%)\end{array}$ & $\begin{array}{c}8.12 \\
(453.15 \%)\end{array}$ & $\begin{array}{c}-1.84 \\
(-102.57 \%)\end{array}$ & $\begin{array}{c}1.36 \\
(75.57 \%)\end{array}$ & $\begin{array}{c}2.79 \\
(155.49 \%)\end{array}$ & $\begin{array}{c}20.61 \\
(1149.30 \%)\end{array}$ \\
\hline $0.1 \%$ transaction costs & $\begin{array}{c}1.95 \\
(108.70 \%)\end{array}$ & $\begin{array}{c}2.61 \\
(145.55 \%)\end{array}$ & $\begin{array}{c}6.34 \\
(353.22 \%)\end{array}$ & $\begin{array}{c}-3.44 \\
(-191.88 \%)\end{array}$ & $\begin{array}{c}-0.33 \\
(-18.62 \%)\end{array}$ & $\begin{array}{c}1.21 \\
(67.40 \%)\end{array}$ & $\begin{array}{c}20.58 \\
(1146.81 \%)\end{array}$ \\
\hline $0.2 \%$ transaction costs & $\begin{array}{c}-1.43 \\
(-79.82 \%)\end{array}$ & $\begin{array}{c}0.07 \\
(3.77 \%)\end{array}$ & $\begin{array}{c}4.55 \\
(253.50 \%)\end{array}$ & $\begin{array}{c}-5.05 \\
(-281.01 \%)\end{array}$ & $\begin{array}{c}-2.02 \\
(-112.62 \%)\end{array}$ & $\begin{array}{c}-0.37 \\
(-20.52 \%)\end{array}$ & $\begin{array}{c}20.56 \\
(1144.32 \%)\end{array}$ \\
\hline $0.35 \%$ transaction costs & $\begin{array}{c}-6.51 \\
(-361.90 \%)\end{array}$ & $\begin{array}{c}-3.75 \\
(-208.37 \%)\end{array}$ & $\begin{array}{c}1.88 \\
(104.28 \%)\end{array}$ & $\begin{array}{c}-7.46 \\
(-414.38 \%)\end{array}$ & $\begin{array}{c}-4.56 \\
(-253.27 \%)\end{array}$ & $\begin{array}{c}-2.74 \\
(-152.06 \%)\end{array}$ & $\begin{array}{c}20.52 \\
(1140.59 \%)\end{array}$ \\
\hline $\begin{array}{l}\text { No. of times of buying (or selling) } \\
\text { the stock for Strategy } 1\end{array}$ & 103 & 80 & 51 & 45 & 52 & 49 & \\
\hline \multicolumn{8}{|c|}{ Stock no. 857} \\
\hline No transaction costs & $\begin{array}{c}3.57 \\
(82.43 \%)\end{array}$ & $\begin{array}{c}6.11 \\
(147.23 \%)\end{array}$ & $\begin{array}{c}4.31 \\
(103.86 \%)\end{array}$ & $\begin{array}{c}0.60 \\
(14.46 \%)\end{array}$ & $\begin{array}{c}1.41 \\
(34.39 \%)\end{array}$ & $\begin{array}{c}-0.76 \\
(-18.10 \%)\end{array}$ & $\begin{array}{c}0.60 \\
(14.46 \%)\end{array}$ \\
\hline $0.1 \%$ transaction costs & $\begin{array}{c}2.13 \\
(49.11 \%)\end{array}$ & $\begin{array}{c}5.11 \\
(123.05 \%)\end{array}$ & $\begin{array}{c}3.48 \\
(83.67 \%)\end{array}$ & $\begin{array}{c}-0.11 \\
(-2.58 \%)\end{array}$ & $\begin{array}{c}0.56 \\
(13.69 \%)\end{array}$ & $\begin{array}{c}-1.74 \\
(-41.46 \%)\end{array}$ & $\begin{array}{c}0.59 \\
(14.23 \%)\end{array}$ \\
\hline $0.2 \%$ transaction costs & $\begin{array}{c}0.69 \\
(15.86 \%) \\
\end{array}$ & $\begin{array}{c}4.11 \\
(98.93 \%)\end{array}$ & $\begin{array}{c}2.64 \\
(63.53 \%) \\
\end{array}$ & $\begin{array}{c}-0.81 \\
(-19.58 \%) \\
\end{array}$ & $\begin{array}{c}-0.29 \\
(-6.96 \%)\end{array}$ & $\begin{array}{c}-2.73 \\
(-64.77 \%)\end{array}$ & $\begin{array}{c}0.58 \\
(14.00 \%)\end{array}$ \\
\hline $0.35 \%$ transaction costs & $\begin{array}{c}-1.47 \\
(-33.89 \%)\end{array}$ & $\begin{array}{c}2.62 \\
(62.83 \%)\end{array}$ & $\begin{array}{c}1.39 \\
(33.40 \%)\end{array}$ & $\begin{array}{c}-1.87 \\
(-45.01 \%)\end{array}$ & $\begin{array}{c}-1.56 \\
(-37.87 \%)\end{array}$ & $\begin{array}{c}-4.20 \\
(-99.66 \%)\end{array}$ & $\begin{array}{c}0.57 \\
(13.66 \%)\end{array}$ \\
\hline $\begin{array}{l}\text { No. of times of buying (or selling) } \\
\text { the stock for Strategy } 1\end{array}$ & 79 & 55 & 43 & 37 & 44 & 50 & \\
\hline \multicolumn{8}{|c|}{ Stock no. 883} \\
\hline No transaction costs & $\begin{array}{c}6.02 \\
(144.19 \%)\end{array}$ & $\begin{array}{c}8.425 \\
(201.80 \%)\end{array}$ & $\begin{array}{c}2.525 \\
(60.48 \%)\end{array}$ & $\begin{array}{c}1.915 \\
(45.87 \%)\end{array}$ & $\begin{array}{c}14.005 \\
(335.45 \%)\end{array}$ & $\begin{array}{c}9.985 \\
(239.16 \%)\end{array}$ & $\begin{array}{c}3.705 \\
(88.74 \%)\end{array}$ \\
\hline $0.1 \%$ transaction costs & $\begin{array}{c}3.79 \\
(90.74 \%) \\
\end{array}$ & $\begin{array}{c}6.87 \\
(164.37 \%)\end{array}$ & $\begin{array}{c}1.40 \\
(33.48 \%)\end{array}$ & $\begin{array}{c}0.49 \\
(11.61 \%)\end{array}$ & $\begin{array}{c}13.28 \\
(317.68 \%)\end{array}$ & $\begin{array}{c}9.15 \\
(218.93 \%) \\
\end{array}$ & $\begin{array}{c}3.69 \\
(88.37 \%) \\
\end{array}$ \\
\hline $0.2 \%$ transaction costs & $\begin{array}{c}1.56 \\
(37.40 \%)\end{array}$ & $\begin{array}{c}5.31 \\
(127.02 \%)\end{array}$ & $\begin{array}{c}0.27 \\
(6.54 \%)\end{array}$ & $\begin{array}{c}-0.94 \\
(-22.59 \%)\end{array}$ & $\begin{array}{c}12.55 \\
(299.94 \%)\end{array}$ & $\begin{array}{c}8.31 \\
(198.74 \%)\end{array}$ & $\begin{array}{c}3.68 \\
(87.99 \%)\end{array}$ \\
\hline $0.35 \%$ transaction costs & $\begin{array}{c}-1.78 \\
(-42.41 \%)\end{array}$ & $\begin{array}{c}2.98 \\
(71.13 \%)\end{array}$ & $\begin{array}{c}-1.42 \\
(-33.78 \%)\end{array}$ & $\begin{array}{c}-3.09 \\
(-73.75 \%)\end{array}$ & $\begin{array}{c}11.45 \\
(273.40 \%)\end{array}$ & $\begin{array}{c}7.06 \\
(168.52 \%)\end{array}$ & $\begin{array}{c}3.66 \\
(87.43 \%)\end{array}$ \\
\hline $\begin{array}{l}\text { No. of times of buying (or selling) } \\
\text { the stock for Strategy } 1\end{array}$ & 94 & 72 & 53 & 56 & 30 & 33 & \\
\hline \multicolumn{8}{|c|}{ Stock no. 941} \\
\hline No transaction costs & $\begin{array}{c}33.75 \\
(128.08 \%)\end{array}$ & $\begin{array}{c}44.50 \\
(168.88 \%)\end{array}$ & $\begin{array}{c}65.40 \\
(248.20 \%) \\
\end{array}$ & $\begin{array}{c}80.95 \\
(307.21 \%)\end{array}$ & $\begin{array}{c}41.80 \\
(158.63 \%)\end{array}$ & $\begin{array}{c}54.15 \\
(216.60 \%) \\
\end{array}$ & $\begin{array}{c}59.35 \\
(225.24 \%)\end{array}$ \\
\hline $0.1 \%$ transaction costs & $\begin{array}{c}17.70 \\
(67.10 \%)\end{array}$ & $\begin{array}{c}34.21 \\
(129.72 \%)\end{array}$ & $\begin{array}{c}57.40 \\
(217.63 \%)\end{array}$ & $\begin{array}{c}73.54 \\
(278.81 \%)\end{array}$ & $\begin{array}{c}33.97 \\
(128.79 \%)\end{array}$ & $\begin{array}{c}46.62 \\
(186.29 \%)\end{array}$ & $\begin{array}{c}59.24 \\
(224.59 \%)\end{array}$ \\
\hline $0.2 \%$ transaction costs & $\begin{array}{c}1.65 \\
(6.25 \%)\end{array}$ & $\begin{array}{c}23.93 \\
(90.63 \%)\end{array}$ & $\begin{array}{c}49.41 \\
(187.12 \%)\end{array}$ & $\begin{array}{c}66.13 \\
(250.47 \%)\end{array}$ & $\begin{array}{c}26.14 \\
(99.02 \%)\end{array}$ & $\begin{array}{c}39.09 \\
(156.05 \%)\end{array}$ & $\begin{array}{c}59.13 \\
(223.94 \%)\end{array}$ \\
\hline $0.35 \%$ transaction costs & $\begin{array}{c}-22.43 \\
(-84.81 \%)\end{array}$ & $\begin{array}{c}8.50 \\
(32.15 \%)\end{array}$ & $\begin{array}{c}37.41 \\
(141.48 \%)\end{array}$ & $\begin{array}{c}55.02 \\
(208.07 \%) \\
\end{array}$ & $\begin{array}{c}14.40 \\
(54.46 \%)\end{array}$ & $\begin{array}{c}27.80 \\
(110.79 \%)\end{array}$ & $\begin{array}{c}58.96 \\
(222.97 \%)\end{array}$ \\
\hline $\begin{array}{l}\text { No. of times of buying (or selling) } \\
\text { the stock for Strategy } 1\end{array}$ & 108 & 68 & 51 & 46 & 51 & 47 & \\
\hline \multicolumn{8}{|c|}{ Stock no. 1109} \\
\hline No transaction costs & $\begin{array}{c}13.92 \\
(1054.55 \%)\end{array}$ & $\begin{array}{c}11.53 \\
(873.11 \%) \\
\end{array}$ & $\begin{array}{c}17.32 \\
(1311.74 \%) \\
\end{array}$ & $\begin{array}{c}13.49 \\
(1021.59 \%) \\
\end{array}$ & $\begin{array}{c}6.82 \\
(524.62 \%) \\
\end{array}$ & $\begin{array}{c}3.25 \\
(187.86 \%) \\
\end{array}$ & $\begin{array}{c}17.62 \\
(1334.85 \%)\end{array}$ \\
\hline $0.1 \%$ transaction costs & $\begin{array}{c}11.20 \\
(847.33 \%)\end{array}$ & $\begin{array}{c}9.40 \\
(711.33 \%)\end{array}$ & $\begin{array}{c}15.79 \\
(1194.73 \%)\end{array}$ & $\begin{array}{c}12.31 \\
(931.88 \%)\end{array}$ & $\begin{array}{c}5.80 \\
(445.99 \%)\end{array}$ & $\begin{array}{c}2.39 \\
(137.85 \%)\end{array}$ & $\begin{array}{c}17.60 \\
(1331.98 \%)\end{array}$ \\
\hline $0.2 \%$ transaction costs & $\begin{array}{c}8.47 \\
(640.52 \%)\end{array}$ & $\begin{array}{c}7.27 \\
(549.87 \%)\end{array}$ & $\begin{array}{c}14.26 \\
(1077.96 \%)\end{array}$ & $\begin{array}{c}11.14 \\
(842.35 \%)\end{array}$ & $\begin{array}{c}4.79 \\
(367.52 \%)\end{array}$ & $\begin{array}{c}1.52 \\
(87.94 \%)\end{array}$ & $\begin{array}{c}17.58 \\
(1329.12 \%)\end{array}$ \\
\hline $0.35 \%$ transaction costs & $\begin{array}{c}4.39 \\
(331.09 \%)\end{array}$ & $\begin{array}{c}4.08 \\
(308.29 \%)\end{array}$ & $\begin{array}{c}11.96 \\
(903.23 \%)\end{array}$ & $\begin{array}{c}9.38 \\
(708.39 \%) \\
\end{array}$ & $\begin{array}{c}3.26 \\
(250.10 \%) \\
\end{array}$ & $\begin{array}{c}0.23 \\
(13.26 \%) \\
\end{array}$ & $\begin{array}{c}17.55 \\
(1324.84 \%)\end{array}$ \\
\hline $\begin{array}{l}\text { No. of times of buying (or selling) } \\
\text { the stock for Strategy } 1\end{array}$ & 91 & 71 & 53 & 37 & 32 & 26 & \\
\hline \multicolumn{8}{|c|}{ Stock no. 2628} \\
\hline No transaction costs & $\begin{array}{c}29.45 \\
(566.35 \%)\end{array}$ & $\begin{array}{c}44.53 \\
(856.35 \%)\end{array}$ & $\begin{array}{c}22.53 \\
(433.27 \%)\end{array}$ & $\begin{array}{c}22.61 \\
(434.81 \%)\end{array}$ & $\begin{array}{c}21.34 \\
(410.38 \%)\end{array}$ & $\begin{array}{c}9.30 \\
(173.83 \%)\end{array}$ & $\begin{array}{c}13.58 \\
(261.15 \%)\end{array}$ \\
\hline $0.1 \%$ transaction costs & $\begin{array}{c}25.75 \\
(494.75 \%)\end{array}$ & $\begin{array}{c}42.09 \\
(808.61 \%)\end{array}$ & $\begin{array}{c}19.74 \\
(379.28 \%)\end{array}$ & $\begin{array}{c}21.12 \\
(405.67 \%)\end{array}$ & $\begin{array}{c}19.39 \\
(372.60 \%)\end{array}$ & $\begin{array}{c}7.84 \\
(146.36 \%)\end{array}$ & $\begin{array}{c}13.56 \\
(260.43 \%)\end{array}$ \\
\hline $0.2 \%$ transaction costs & $\begin{array}{c}22.06 \\
(423.30 \%)\end{array}$ & $\begin{array}{c}39.65 \\
(760.97 \%)\end{array}$ & $\begin{array}{c}16.95 \\
(325.40 \%)\end{array}$ & $\begin{array}{c}19.62 \\
(376.59 \%) \\
\end{array}$ & $\begin{array}{c}17.45 \\
(334.89 \%)\end{array}$ & $\begin{array}{c}6.38 \\
(118.94 \%) \\
\end{array}$ & $\begin{array}{c}13.53 \\
(259.71 \%)\end{array}$ \\
\hline $0.35 \%$ transaction costs & $\begin{array}{c}16.51 \\
(316.39 \%)\end{array}$ & $\begin{array}{c}35.99 \\
(689.69 \%)\end{array}$ & $\begin{array}{c}12.77 \\
(244.77 \%)\end{array}$ & $\begin{array}{c}17.38 \\
(333.07 \%) \\
\end{array}$ & $\begin{array}{c}14.53 \\
(278.47 \%)\end{array}$ & $\begin{array}{c}4.18 \\
(77.92 \%) \\
\end{array}$ & $\begin{array}{c}13.50 \\
(258.63 \%) \\
\end{array}$ \\
\hline $\begin{array}{l}\text { No. of times of buying (or selling) } \\
\text { the stock for Strategy } 1\end{array}$ & 82 & 57 & 55 & 34 & 40 & 29 & \\
\hline
\end{tabular}


From Table 3, the performance of Strategy 1 varies among different stocks. The best performance stock is stock no. 5, where Strategy 1 outperforms "buy-andhold" for all cases except for $0.35 \%$ transaction costs with moving-window sizes 40 and 120. The worst performing stocks are stocks no. 688 and no. 1109, where Strategy 1 underperforms "buy-and-hold" for all cases. Furthermore, Strategy 1 outperforms "buy-and-hold" on the six nonproperty stocks for 98 out of 144 cases, compared with 39 out of 144 cases on the six property stocks, showing that Strategy 1 is more effective on non-property stocks than on property stocks. Strategy 1 outperforms "buy-andhold" on the six non-China enterprise stocks for 80 out of 144 cases, compared with 48 out of 144 cases on the six China enterprise stocks, showing that Strategy 1 is more effective on non-China enterprise stocks than on China enterprise stocks. Strategy 1 beats "buy-and-hold" for less than half (127) of the total of 288 cases, reflecting that "buy-and-hold" is slightly superior to Strategy 1 in overall.

There are several similarities between our results and Hui and Chan (2018)'s results. Firstly, as the movingwindow size increases, the profit of Strategy 1 increases first, but then eventually decreases. Secondly, an increase in transaction costs reduces the profit of Strategy 1 by a much larger extent than the profit when applying the "buy-and-hold" strategy. Furthermore, when the movingwindow size increases, a rise in transaction costs would, in general, reduce the profit of Strategy 1 by a smaller extent. In addition, the number of times of buying (or selling) the stock index for Strategy 1 generally decreases as the moving-window size increases (but with a few exceptions). The reasons for these similarities are explained in Hui and Chan (2018).

Note that stock no. 5, the best performing stock for Strategy 1 , is the only stock with a negative return throughout the whole period. On the other hand, stocks no. 688 and 1109, the worst performing stocks for Strategy 1, yields the largest return over the period of observation (both over $1000 \%)$. This shows that Strategy 1 works better on adverse performing stocks. This result is similar to Hui and Chan (2018)'s result and the reason is explained in Hui and Chan (2018). Besides return, the average no. of times of buying (or selling) the stock index for Strategy 1 also affects the performance of Strategy 1. Stock no. 388 has the smallest average no. of times of buying (or selling) the stock for Strategy 1, and Strategy 1 outperforms "buy-and-hold" for stock no. 388 for 16 out of 24 cases. On the other hand, stock no. 688 have the largest average no. of times of buying (or selling) the stock for Strategy 1, and Strategy 1 underperforms "buy-and-hold" for this stock for all cases. This result is also similar to Hui and Chan (2018)'s result and the reason is explained in Hui and Chan (2018).

Then we find the optimal moving-window size of Strategy 1 for each stock, under $0 \%, 0.1 \%, 0.2 \%$ and $0.35 \%$ transaction costs. The Table 4 shows the optimal moving-window sizes of Strategy 1 for the 12 stocks under the four different amounts of transaction costs (the cases of which Strategy 1 outperforms "buy-and-hold" are highlighted in red).
Table 4 shows that the optimal moving-window size of Strategy 1 varies among the 12 stocks. Stock no. 388 has the smallest optimal moving-window size, which is 7 for no transaction costs and 42 for $0.1 \%, 0.2 \%$ and $0.35 \%$ transaction costs. Stock no. 883 has the largest optimal moving-window size, which is 197 for zero and $0.1 \%$ transaction costs, and 199 for $0.2 \%$ and $0.35 \%$ transaction costs. Other stocks have optimal moving-window sizes ranging from 74 to 142 . Referring back to Table 3, we can see that stock no. 388 has the smallest average no. of times of buying (or selling) the stock for Strategy 1. This contributes to its smallest optimal moving-window size in this way: a smaller average no. of times of buying (or selling) the stock for Strategy 1 means that $\hat{\mu}_{i}(n)$ changes sign less frequently, and the length of "holding periods" (periods of which $\hat{\mu}_{i-1}(n) \geq 0$ ) and "non-holding periods" (periods of which $\hat{\mu}_{i-1}(n) \geq 0$ ) are longer, so there is a lower chance that $\hat{\mu}_{i-1}(n)<0$, but the stock price is still rising on day $i$. Therefore, Strategy 1 is more likely to outperform the "buy-and-hold" strategy for smaller moving-window sizes for stock no. 388 , resulting in its smaller optimal moving-window size. Compared with Hui and Chan (2018)'s result, our 12 stocks have smaller optimal moving-window sizes in overall than the 12 stock indices in Hui and Chan (2018) do. The main reason is that the average no. of times of buying (or selling) the stock for Strategy 1 for our 12 stocks is much smaller than that for the 12 stock indices in Hui and Chan (2018).

From Table 4, we can see that the optimal strategy outperforms the "buy-and-hold" strategy for almost all cases (43 out of 48). The exceptional cases are stock no. 688, where the optimal strategy underperforms "buy-and-hold" for all cases, and stock no. 1109, where "buy-and-hold" outperforms the optimal strategy for $0.35 \%$ transaction costs only. This shows that if we choose a suitable movingwindow size, Strategy 1 can really beat the "buy-and-hold" strategy for most cases. In fact, both stocks of which the optimal strategy underperforms "buy-and-hold" are stocks of Chinese property companies, of which the stock prices soar for over ten times during the period of observation due to the Chinese property market boom in recent years.

Table 4 also shows the link between the amount of transaction costs and the optimal moving-window size for Strategy 1. For 9 of the 12 stocks, the optimal movingwindow size for Strategy 1 remains the same for all four different amounts of transaction costs. For the remaining three stocks, for two of them (stocks no. 388 and no. 883), the optimal moving-window size increases as the amount of transaction costs rises. For example, the optimal moving-window size of Strategy 1 for stock no. 388 is 7 without transaction costs, but the optimal moving-window size increases to 42 with $0.1 \%, 0.2 \%$ or $0.35 \%$ transaction costs. From Table 4, the number of times we buy (or sell) stock no. 388 for Strategy 1 is 199 when the moving-window size is 7 , but this number drops significantly to 58 when the moving-window size increases to 42. As explained in Hui and Chan (2018), a smaller number of times of 
Table 4. The optimal moving-window sizes of Strategy 1 for the 12 stocks (the red entries indicate that Strategy 1 beats "buy-andhold", while the numbers in the brackets indicate the percentage profits)

\begin{tabular}{|c|c|c|c|c|}
\hline Transaction cost & buy-and-hold & Optimal strategy & $\begin{array}{l}\text { Optimal moving- } \\
\text { window size }\end{array}$ & $\begin{array}{l}\text { No. of times of buying } \\
\text { (or selling) the stock for } \\
\text { the optimal strategy }\end{array}$ \\
\hline \multicolumn{5}{|c|}{ Stock no. 5} \\
\hline $0 \%$ & $\begin{array}{c}-68.66 \\
(-55.75 \%) \\
\end{array}$ & $\begin{array}{c}17.58 \\
(14.28 \%) \\
\end{array}$ & 77 & 60 \\
\hline $0.1 \%$ & $\begin{array}{c}-68.84 \\
(-55.84 \%) \\
\end{array}$ & $\begin{array}{c}6.55 \\
(5.31 \%) \\
\end{array}$ & 77 & 60 \\
\hline $0.2 \%$ & $\begin{array}{c}-69.01 \\
(-55.92 \%) \\
\end{array}$ & $\begin{array}{c}-4.48 \\
(-3.63 \%) \\
\end{array}$ & 77 & 60 \\
\hline $0.35 \%$ & $\begin{array}{c}-69.28 \\
(-56.06 \%) \\
\end{array}$ & $\begin{array}{c}-21.03 \\
(-17.02 \%) \\
\end{array}$ & 77 & 60 \\
\hline \multicolumn{5}{|c|}{ Stock no. 12} \\
\hline $0 \%$ & $\begin{array}{c}11.65 \\
(38.37 \%)\end{array}$ & $\begin{array}{c}41.47 \\
(136.62 \%)\end{array}$ & 79 & 50 \\
\hline $0.1 \%$ & $\begin{array}{c}11.57 \\
(38.10 \%)\end{array}$ & $\begin{array}{c}37.75 \\
(124.25 \%)\end{array}$ & 79 & 50 \\
\hline $0.2 \%$ & $\begin{array}{c}11.50 \\
(37.82 \%)\end{array}$ & $\begin{array}{c}34.03 \\
(111.91 \%) \\
\end{array}$ & 79 & 50 \\
\hline $0.35 \%$ & $\begin{array}{c}11.39 \\
(37.41 \%) \\
\end{array}$ & $\begin{array}{c}28.46 \\
(93.44 \%) \\
\end{array}$ & 79 & 50 \\
\hline \multicolumn{5}{|c|}{ Stock no. 16} \\
\hline $0 \%$ & $\begin{array}{c}6.05 \\
(7.78 \%)\end{array}$ & $\begin{array}{c}114.90 \\
(147.78 \%)\end{array}$ & 82 & 53 \\
\hline $0.1 \%$ & $\begin{array}{c}5.89 \\
(7.57 \%) \\
\end{array}$ & $\begin{array}{c}104.24 \\
(133.93 \%)\end{array}$ & 82 & 53 \\
\hline $0.2 \%$ & $\begin{array}{c}5.73 \\
(7.35 \%)\end{array}$ & $\begin{array}{c}93.58 \\
(120.11 \%)\end{array}$ & 82 & 53 \\
\hline $0.35 \%$ & $\begin{array}{c}5.48 \\
(7.03 \%) \\
\end{array}$ & $\begin{array}{c}77.58 \\
(99.44 \%) \\
\end{array}$ & 82 & 53 \\
\hline \multicolumn{5}{|c|}{ Stock no. 83} \\
\hline $0 \%$ & $\begin{array}{c}2.93 \\
(42.06 \%)\end{array}$ & $\begin{array}{c}13.23 \\
(190.25 \%)\end{array}$ & 102 & 47 \\
\hline $0.1 \%$ & $\begin{array}{c}2.91 \\
(41.77 \%)\end{array}$ & $\begin{array}{c}12.10 \\
(173.77 \%)\end{array}$ & 102 & 47 \\
\hline $0.2 \%$ & $\begin{array}{c}2.89 \\
(41.49 \%)\end{array}$ & $\begin{array}{c}10.96 \\
(157.33 \%)\end{array}$ & 102 & 47 \\
\hline $0.35 \%$ & $\begin{array}{c}2.87 \\
(41.07 \%) \\
\end{array}$ & $\begin{array}{c}9.26 \\
(132.73 \%) \\
\end{array}$ & 102 & 47 \\
\hline \multicolumn{5}{|c|}{ Stock no. 101} \\
\hline $0 \%$ & $\begin{array}{c}2.26 \\
(18.83 \%) \\
\end{array}$ & $\begin{array}{c}21.68 \\
(180.67 \%)\end{array}$ & 110 & 56 \\
\hline $0.1 \%$ & $\begin{array}{c}2.23 \\
(18.60 \%) \\
\end{array}$ & $\begin{array}{c}19.65 \\
(163.59 \%) \\
\end{array}$ & 110 & 56 \\
\hline $0.2 \%$ & $\begin{array}{c}2.21 \\
(18.36 \%)\end{array}$ & $\begin{array}{c}17.62 \\
(146.55 \%)\end{array}$ & 110 & 56 \\
\hline $0.35 \%$ & $\begin{array}{c}2.17 \\
(18.00 \%) \\
\end{array}$ & $\begin{array}{c}14.58 \\
(121.06 \%) \\
\end{array}$ & 110 & 56 \\
\hline \multicolumn{5}{|c|}{ Stock no. 388} \\
\hline $0 \%$ & $\begin{array}{c}149.50 \\
(718.75 \%)\end{array}$ & $\begin{array}{c}463.00 \\
(2225.96 \%)\end{array}$ & 7 & 199 \\
\hline $0.1 \%$ & $\begin{array}{c}149.31 \\
(717.11 \%)\end{array}$ & $\begin{array}{c}417.25 \\
(2004.00 \%)\end{array}$ & 42 & 58 \\
\hline $0.2 \%$ & $\begin{array}{c}149.12 \\
(715.48 \%)\end{array}$ & $\begin{array}{c}402.25 \\
(1930.03 \%)\end{array}$ & 42 & 58 \\
\hline $0.35 \%$ & $\begin{array}{c}148.83 \\
(713.04 \%) \\
\end{array}$ & $\begin{array}{c}379.75 \\
(1819.35 \%) \\
\end{array}$ & 42 & 58 \\
\hline \multicolumn{5}{|c|}{ Stock no. 688} \\
\hline $0 \%$ & $\begin{array}{c}20.61 \\
1149.30 \% \\
\end{array}$ & $\begin{array}{c}15.11 \\
842.50 \% \\
\end{array}$ & 114 & 56 \\
\hline $0.1 \%$ & $\begin{array}{c}20.58 \\
(1146.81 \%)\end{array}$ & $\begin{array}{c}13.21 \\
(735.93 \%)\end{array}$ & 114 & 56 \\
\hline $0.2 \%$ & $\begin{array}{c}20.56 \\
(1144.32 \%)\end{array}$ & $\begin{array}{c}11.31 \\
(629.58 \%)\end{array}$ & 114 & 56 \\
\hline $0.35 \%$ & $\begin{array}{c}20.52 \\
(1140.59 \%)\end{array}$ & $\begin{array}{c}8.46 \\
(470.45 \%)\end{array}$ & 114 & 56 \\
\hline
\end{tabular}


End of Table 4

\begin{tabular}{|c|c|c|c|c|}
\hline Transaction cost & buy-and-hold & Optimal strategy & $\begin{array}{l}\text { Optimal moving- } \\
\text { window size }\end{array}$ & $\begin{array}{l}\text { No. of times of buying } \\
\text { (or selling) the stock for } \\
\text { the optimal strategy }\end{array}$ \\
\hline \multicolumn{5}{|c|}{ Stock no. 857} \\
\hline $0 \%$ & $\begin{array}{c}0.60 \\
(14.46 \%) \\
\end{array}$ & $\begin{array}{c}7.96 \\
(191.93 \%) \\
\end{array}$ & 74 & 70 \\
\hline $0.1 \%$ & $\begin{array}{c}0.59 \\
(14.23 \%)\end{array}$ & $\begin{array}{c}6.71 \\
(161.64 \%)\end{array}$ & 74 & 70 \\
\hline $0.2 \%$ & $\begin{array}{c}0.58 \\
(14.00 \%)\end{array}$ & $\begin{array}{c}5.46 \\
(131.41 \%) \\
\end{array}$ & 74 & 70 \\
\hline $0.35 \%$ & $\begin{array}{c}0.57 \\
(13.66 \%)\end{array}$ & $\begin{array}{c}3.59 \\
(86.19 \%) \\
\end{array}$ & 74 & 70 \\
\hline \multicolumn{5}{|c|}{ Stock no. 883} \\
\hline $0 \%$ & $\begin{array}{c}3.71 \\
(88.74 \%)\end{array}$ & $\begin{array}{c}14.74 \\
(352.93 \%)\end{array}$ & 197 & 34 \\
\hline $0.1 \%$ & $\begin{array}{c}3.69 \\
(88.37 \%)\end{array}$ & $\begin{array}{c}13.91 \\
(332.93 \%)\end{array}$ & 197 & 34 \\
\hline $0.2 \%$ & $\begin{array}{c}3.68 \\
(87.99 \%) \\
\end{array}$ & $\begin{array}{c}13.09 \\
(312.99 \%)\end{array}$ & 199 & 27 \\
\hline $0.35 \%$ & $\begin{array}{c}3.66 \\
(87.43 \%) \\
\end{array}$ & $\begin{array}{c}12.13 \\
(289.58 \%)\end{array}$ & 199 & 27 \\
\hline \multicolumn{5}{|c|}{ Stock no. 941} \\
\hline $0 \%$ & $\begin{array}{c}59.35 \\
(225.24 \%) \\
\end{array}$ & $\begin{array}{c}90.90 \\
(344.97 \%)\end{array}$ & 142 & 56 \\
\hline $0.1 \%$ & $\begin{array}{c}59.24 \\
(224.59 \%)\end{array}$ & $\begin{array}{c}81.90 \\
(310.52 \%) \\
\end{array}$ & 142 & 56 \\
\hline $0.2 \%$ & $\begin{array}{c}59.13 \\
(223.94 \%)\end{array}$ & $\begin{array}{c}72.91 \\
(276.14 \%)\end{array}$ & 142 & 56 \\
\hline $0.35 \%$ & $\begin{array}{c}58.96 \\
(222.97 \%) \\
\end{array}$ & $\begin{array}{c}59.67 \\
(225.64 \%) \\
\end{array}$ & 140 & 55 \\
\hline \multicolumn{5}{|c|}{ Stock no. 1109} \\
\hline $0 \%$ & $\begin{array}{c}17.62 \\
(1334.85 \%)\end{array}$ & $\begin{array}{c}21.90 \\
(1659.09 \%)\end{array}$ & 98 & 56 \\
\hline $0.1 \%$ & $\begin{array}{c}17.60 \\
(1331.98 \%)\end{array}$ & $\begin{array}{c}20.21 \\
(1529.90 \%) \\
\end{array}$ & 98 & 56 \\
\hline $0.2 \%$ & $\begin{array}{c}17.58 \\
(1329.12 \%)\end{array}$ & $\begin{array}{c}18.53 \\
(1400.97 \%)\end{array}$ & 98 & 56 \\
\hline $0.35 \%$ & $\begin{array}{c}17.55 \\
(1324.84) \\
\end{array}$ & $\begin{array}{c}16.00 \\
(1208.06 \%)\end{array}$ & 98 & 56 \\
\hline \multicolumn{5}{|c|}{ Stock no. 2628} \\
\hline $0 \%$ & $\begin{array}{c}13.58 \\
(261.15 \%)\end{array}$ & $\begin{array}{c}48.20 \\
(926.92 \%)\end{array}$ & 88 & 45 \\
\hline $0.1 \%$ & $\begin{array}{c}13.56 \\
(260.43 \%)\end{array}$ & $\begin{array}{c}46.13 \\
(886.21 \%) \\
\end{array}$ & 88 & 45 \\
\hline $0.2 \%$ & $\begin{array}{c}13.53 \\
(259.71 \%) \\
\end{array}$ & $\begin{array}{c}44.06 \\
(845.58 \%) \\
\end{array}$ & 88 & 45 \\
\hline $0.35 \%$ & $\begin{array}{c}13.50 \\
(258.63 \%) \\
\end{array}$ & $\begin{array}{c}40.95 \\
(784.78 \%)\end{array}$ & 88 & 45 \\
\hline
\end{tabular}

buying (or selling) the stock for Strategy 1 would cause the resulting profit of Strategy 1 to fall by a smaller extent when the amount of transaction costs increases. This leads to an increase in the optimal moving-window size. Stock no. 941 is the only exception, with an optimal window size of 142 with zero, 0.1 or $0.2 \%$ transaction costs, and 140 with $0.35 \%$ transaction costs. The reason is that the number of times of buying (or selling) this stock for Strategy 1 is greater with a moving-window size of 142 (56 times) than with a moving-window size of 140 (55 times).

\subsection{Profit of Strategy 1 during different times throughout the period}

The optimal strategy described in the previous sub-section considers the whole period of observation. However, during different times of the period, the optimal moving-window size (and hence the optimal strategy) may be different. To investigate how the optimal mobbing-window size varies with time, in this sub-section, we use a graphical method to compare the resulting profits of the "buy-and-hold" strategy and Strategy 1 using the 6 selected moving-window sizes $(40,80$, $120,160,200,240)$ during different times along the whole period of observation. For the sake of convenience, we only consider the case without transaction costs. The results are shown in Figures 1, 2, 3, 4, 5, 6, 7, 8, 9, 10, 11 and 12.

The numbers $40,80,120,160,200$ and 240 in the above figures indicate the moving-window sizes of Strategy 1. From the above figures, there are some periods during which Strategy 1 and "buy-and-hold" move in the same direction. These periods correspond to "holding periods" where $\hat{\mu}_{i-1}(n) \geq 0$. During other periods, our 
5 HK Equity

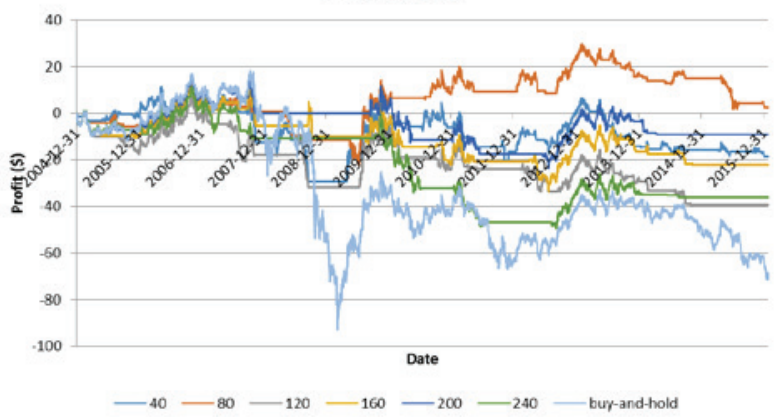

Figure 1. Profits of Strategy 1 and "buy-and-hold" on stock no. 5 (without transaction costs)

12 HK Equity

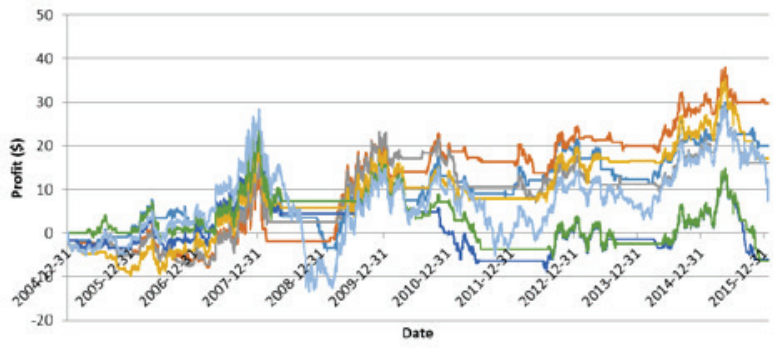

— $^{40}$ - $^{80}$ - $^{120}$ - $^{160}$ — $^{200}$ — $^{240}$ — buy.and.hold

Figure 2. Profits of Strategy 1 and "buy-and-hold" on stock no. 12 (without transaction costs)

\section{HK Equity}

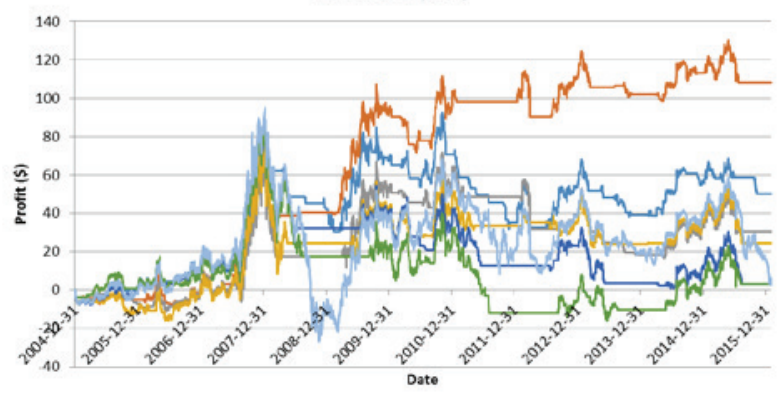

Figure 3. Profits of Strategy 1 and "buy-and-hold" on stock no. 16 (without transaction costs)

\section{HK Equity}

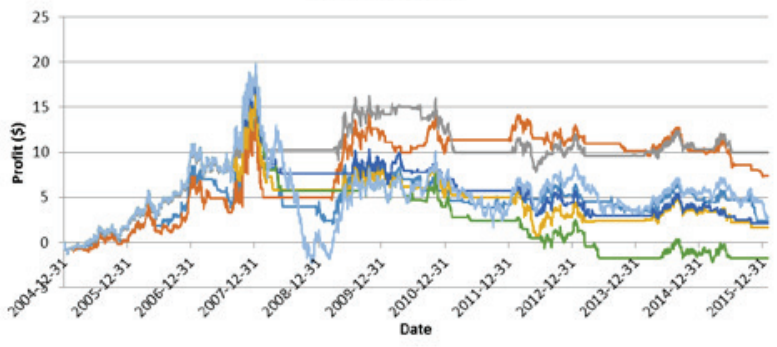

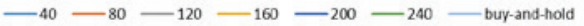

Figure 4. Profits of Strategy 1 and "buy-and-hold" on stock no. 83 (without transaction costs)
101 HK Equity

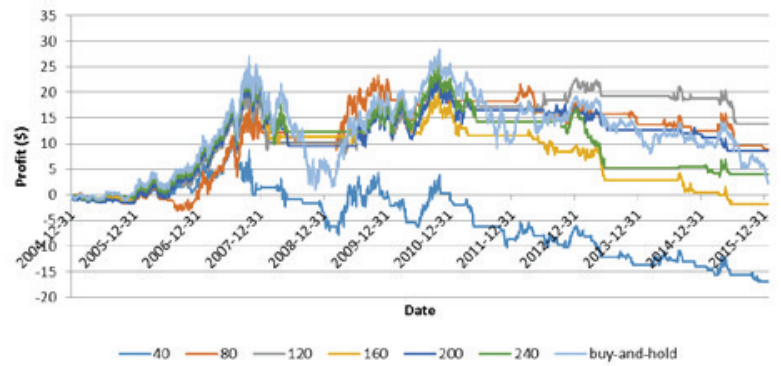

Figure 5. Profits of Strategy 1 and "buy-and-hold" on stock no. 101 (without transaction costs)

388 HK Equity

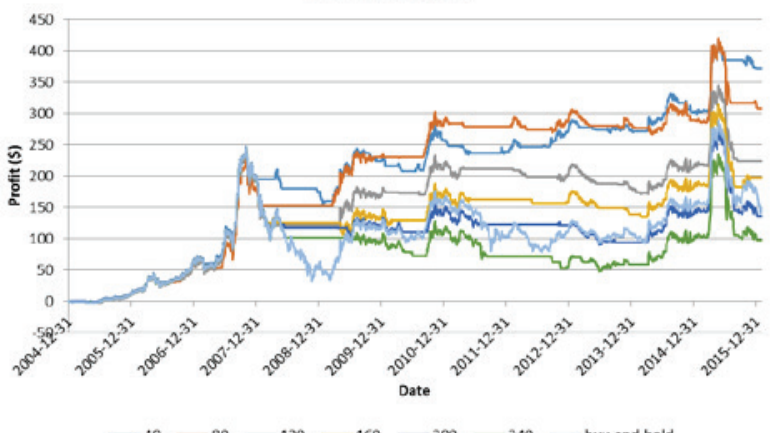

Figure 6. Profits of Strategy 1 and "buy-and-hold" on stock no. 388 (without transaction costs)

688 HK Equity

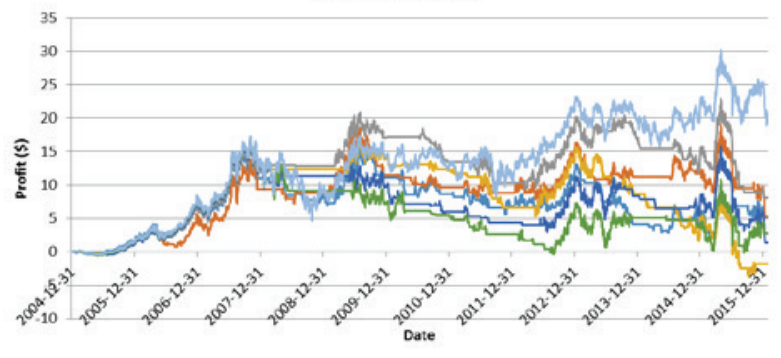

Figure 7. Profits of Strategy 1 and "buy-and-hold" on stock no. 688 (without transaction costs)

857 HK Equity

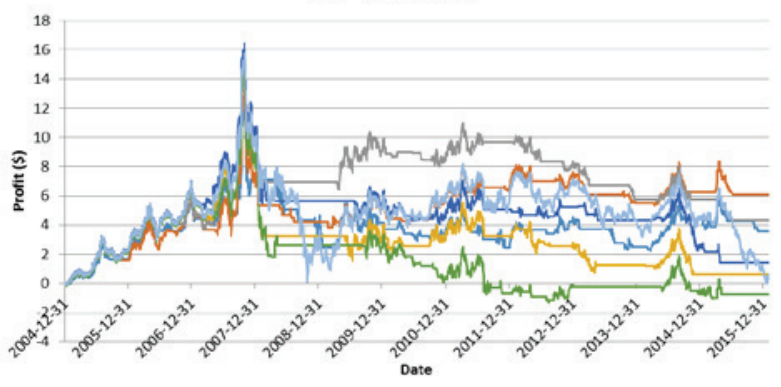

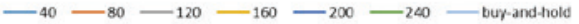

Figure 8. Profits of Strategy 1 and "buy-and-hold" on stock no. 857 (without transaction costs) 


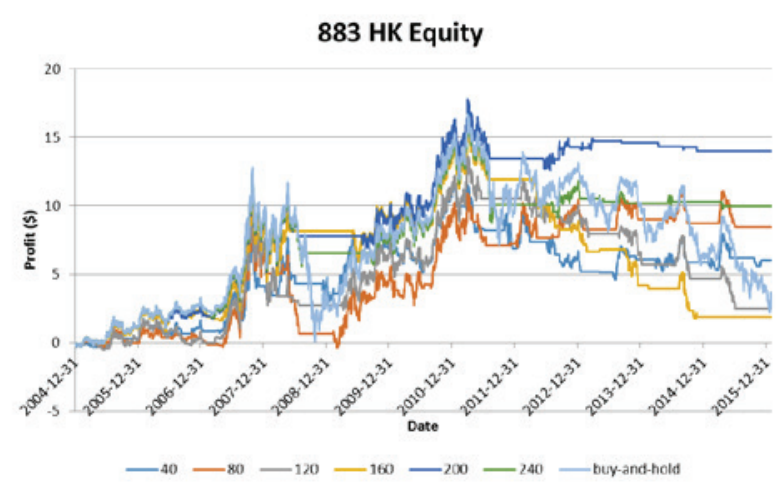

Figure 9. Profits of Strategy 1 and "buy-and-hold" on stock no. 883 (without transaction costs)

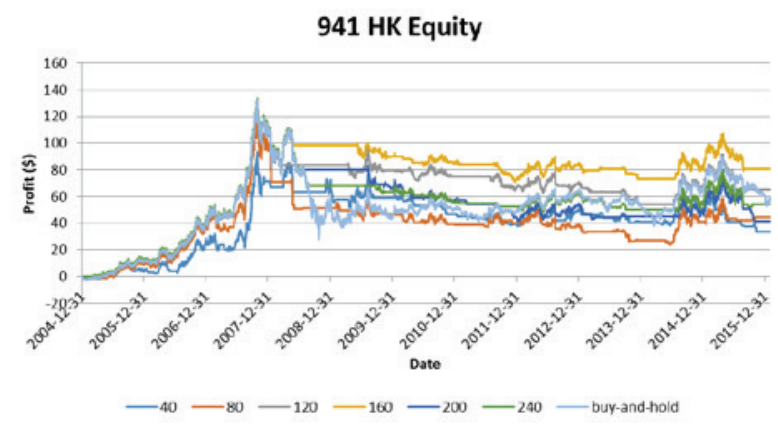

Figure 10. Profits of Strategy 1 and "buy-and-hold" on stock no. 941 (without transaction costs)

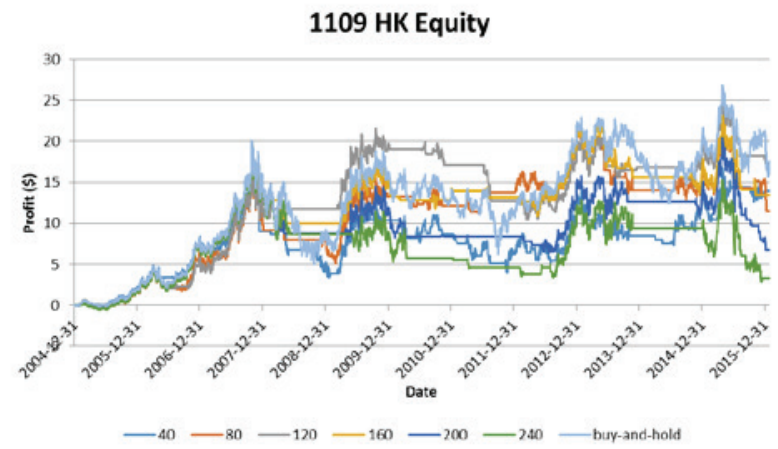

Figure 11. Profits of Strategy 1 and "buy-and-hold" on stock no. 1109 (without transaction costs)

2628 HK Equity

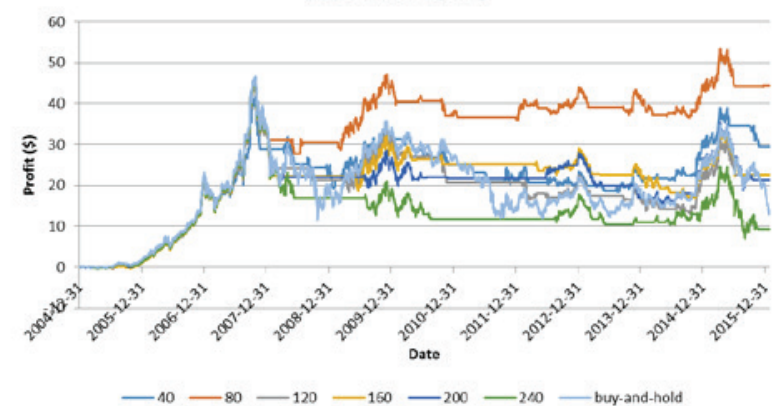

Figure 12. Profits of Strategy 1 and "buy-and-hold" on stock no. 2628 (without transaction costs) strategy moves horizontally, while "buy-and-hold" moves as normal. These periods correspond to "non-holding periods" where $\hat{\mu}_{i-1}(n)<0$. Hence it is the movement of stock prices during the "non-holding period" which makes the difference in profits between the strategies. Note that for Strategy 1, the "holding periods" and "non-holding periods" are different for different movingwindow sizes. Since a larger moving-window size would result in a "smoothing effect", the "non-holding periods" for Strategy 1 are generally longer when using larger moving-window sizes. We can also see that Strategy 1 outperforms "buy-and-hold" during some periods, but underperforms "buy-and-hold" during other periods. The "optimal" moving-window size for Strategy 1 also varies from time to time. For example, for stock no. 388, the "optimal" moving-window size is 80 during 20102013, but changes to 40 since mid-2015.

Similar to Hui and Chan (2018)'s results, for most of the 12 stocks, Strategy 1 outperforms "buy-and-hold" the most during the period late 2008-early 2009. This period corresponds to the time when the global financial crisis was most severe when many stock markets fell sharply to a trough. On the other hand, during periods of which the stock market is on a rising trend (e.g. 2005-2007), Strategy 1 tends to underperform "buy-and-hold". The reason for this result is explained in Hui and Chan (2018). In particular, stock no. 5 is the worst performing stock during the period of observation (-56\% return during the period), but this is the stock of which Strategy 1 beats "buy-and-hold" by the largest extent. As seen from Figure 12, the gap between "buy-and-hold" and other lines become wider and wider during late 2007-early 2009, where the global financial crisis broke out, causing the stock price to fall sharply, creating a long "non-holding period" for Strategy 1 (especially for larger moving-window sizes). Hence the gap widens. From 2009 onwards, Strategy 1 outperforms the "buy-and-hold" strategy no matter which moving-window size we choose, except in the first half of 2011 when Strategy 1 underperforms "buy-and-hold" for some times. This shows that Strategy 1 is particularly effective on adverse performing stocks, which is similar to Hui and Chan (2018)'s result that their strategy beats "buy-and-hold" the most on EPGR index, which is the worst performing index during the period.

\subsection{Repeat of test using different ending dates of the period}

Here we repeat the test again, but the ending date is changed to December 31, 2008 and December 31, 2012 (the corresponding strategies are called Strategy 2 and Strategy 3 respectively, as in Section 4). As in Sub-section 5.1, we select the 6 different moving-window sizes $n$ for both Strategies 2 and 3: 40, 80, 120, 160, 200, 240. We compare the resulting profit of the strategies with that of "buy-and-hold". The results are shown in Tables 5 and 6. 
Table 5. Comparison between the profits of Strategy 2 and "buy-and-hold" (the red entries indicate that Strategy 2 beats "buy-and-hold", while the numbers in the brackets indicate the percentage profits)

\begin{tabular}{|c|c|c|c|c|c|c|c|}
\hline Moving-window size & 40 & 80 & 120 & 160 & 200 & 240 & buy-and-hold \\
\hline \multicolumn{8}{|c|}{ Stock no. 5} \\
\hline No transaction costs & $\begin{array}{c}-29.17 \\
(-23.68 \%)\end{array}$ & $\begin{array}{c}-11.57 \\
(-9.40 \%)\end{array}$ & $\begin{array}{c}-31.95 \\
(-25.94 \%)\end{array}$ & $\begin{array}{c}-10.18 \\
(-8.27 \%)\end{array}$ & $\begin{array}{c}-0.18 \\
(-0.15 \%)\end{array}$ & $\begin{array}{c}-10.74 \\
(-8.72 \%)\end{array}$ & $\begin{array}{c}-54.91 \\
(-44.59 \%)\end{array}$ \\
\hline $0.1 \%$ transaction costs & $\begin{array}{c}-38.52 \\
(-31.24 \%)\end{array}$ & $\begin{array}{c}-17.11 \\
(-13.88 \%)\end{array}$ & $\begin{array}{c}-39.64 \\
(-32.15 \%)\end{array}$ & $\begin{array}{c}-14.94 \\
(-12.12 \%)\end{array}$ & $\begin{array}{c}-2.46 \\
(-1.99 \%) \\
\end{array}$ & $\begin{array}{c}-13.49 \\
(-10.94 \%)\end{array}$ & $\begin{array}{c}-55.10 \\
(-44.70 \%)\end{array}$ \\
\hline $0.2 \%$ transaction costs & $\begin{array}{c}-47.87 \\
(-38.79 \%)\end{array}$ & $\begin{array}{c}-22.64 \\
(-18.35 \%)\end{array}$ & $\begin{array}{c}-47.33 \\
(-38.35 \%)\end{array}$ & $\begin{array}{c}-19.70 \\
(-15.96 \%)\end{array}$ & $\begin{array}{c}-4.73 \\
(-3.84 \%)\end{array}$ & $\begin{array}{c}-16.23 \\
(-13.15 \%)\end{array}$ & $\begin{array}{c}-55.29 \\
(-44.81 \%)\end{array}$ \\
\hline $0.35 \%$ transaction costs & $\begin{array}{c}-61.89 \\
(-50.08 \%)\end{array}$ & $\begin{array}{c}-30.94 \\
(-25.03 \%)\end{array}$ & $\begin{array}{c}-58.86 \\
(-47.63 \%)\end{array}$ & $\begin{array}{c}-26.84 \\
(-21.72 \%)\end{array}$ & $\begin{array}{c}-8.15 \\
(-6.59 \%)\end{array}$ & $\begin{array}{c}-20.35 \\
(-16.46 \%)\end{array}$ & $\begin{array}{c}-55.58 \\
(-44.97 \%)\end{array}$ \\
\hline $\begin{array}{l}\text { No. of times of buying (or selling) } \\
\text { the stock for Strategy } 2\end{array}$ & 38 & 22 & 31 & 20 & 9 & 11 & \\
\hline \multicolumn{8}{|c|}{ Stock no. 12} \\
\hline No transaction costs & $\begin{array}{c}-0.12 \\
(-0.38 \%)\end{array}$ & $\begin{array}{c}-1.92 \\
(-6.31 \%)\end{array}$ & $\begin{array}{c}2.59 \\
(8.54 \%)\end{array}$ & $\begin{array}{c}5.75 \\
(18.94 \%)\end{array}$ & $\begin{array}{c}4.47 \\
(14.73 \%)\end{array}$ & $\begin{array}{c}7.25 \\
(27.41 \%) \\
\end{array}$ & $\begin{array}{c}-8.79 \\
(-28.96 \%)\end{array}$ \\
\hline $0.1 \%$ transaction costs & $\begin{array}{c}-2.25 \\
(-7.41 \%)\end{array}$ & $\begin{array}{c}-3.32 \\
(-10.91 \%)\end{array}$ & $\begin{array}{c}1.49 \\
(4.89 \%)\end{array}$ & $\begin{array}{c}4.45 \\
(14.66 \%)\end{array}$ & $\begin{array}{c}2.85 \\
(9.38 \%) \\
\end{array}$ & $\begin{array}{c}6.29 \\
(23.75 \%) \\
\end{array}$ & $\begin{array}{c}-8.84 \\
(-29.10 \%)\end{array}$ \\
\hline $0.2 \%$ transaction costs & $\begin{array}{c}-4.38 \\
(-14.42 \%)\end{array}$ & $\begin{array}{c}-4.72 \\
(-15.50 \%)\end{array}$ & $\begin{array}{c}0.38 \\
(1.25 \%)\end{array}$ & $\begin{array}{c}3.16 \\
(10.39 \%)\end{array}$ & $\begin{array}{c}1.23 \\
(4.03 \%)\end{array}$ & $\begin{array}{c}5.32 \\
(20.09 \%)\end{array}$ & $\begin{array}{c}-8.89 \\
(-29.24 \%)\end{array}$ \\
\hline $0.35 \%$ transaction costs & $\begin{array}{c}-7.59 \\
(-24.90 \%)\end{array}$ & $\begin{array}{c}-6.82 \\
(-22.38 \%)\end{array}$ & $\begin{array}{c}-1.28 \\
(-4.19 \%)\end{array}$ & $\begin{array}{c}1.22 \\
(4.00 \%)\end{array}$ & $\begin{array}{c}-1.21 \\
(-3.97 \%)\end{array}$ & $\begin{array}{c}3.88 \\
(14.62 \%)\end{array}$ & $\begin{array}{c}-8.97 \\
(-29.45 \%)\end{array}$ \\
\hline $\begin{array}{l}\text { No. of times of buying (or selling) } \\
\text { the stock for Strategy } 2\end{array}$ & 30 & 21 & 18 & 21 & 24 & 15 & \\
\hline \multicolumn{8}{|c|}{ Stock no. 16} \\
\hline No transaction costs & $\begin{array}{c}42.45 \\
(54.60 \%)\end{array}$ & $\begin{array}{c}40.40 \\
(51.96 \%)\end{array}$ & $\begin{array}{c}17.30 \\
(22.25 \%)\end{array}$ & $\begin{array}{c}24.45 \\
(31.45 \%)\end{array}$ & $\begin{array}{c}32.25 \\
(41.48 \%)\end{array}$ & $\begin{array}{c}17.30 \\
(22.25 \%)\end{array}$ & $\begin{array}{c}-13.15 \\
(-16.91 \%)\end{array}$ \\
\hline $0.1 \%$ transaction costs & $\begin{array}{c}37.87 \\
(48.66 \%)\end{array}$ & $\begin{array}{c}36.67 \\
(47.12 \%)\end{array}$ & $\begin{array}{c}12.83 \\
(16.48 \%)\end{array}$ & $\begin{array}{c}21.14 \\
(27.16 \%)\end{array}$ & $\begin{array}{c}30.28 \\
(38.90 \%)\end{array}$ & $\begin{array}{c}14.86 \\
(19.10 \%)\end{array}$ & $\begin{array}{c}-13.29 \\
(-17.08 \%)\end{array}$ \\
\hline $0.2 \%$ transaction costs & $\begin{array}{c}33.30 \\
(42.74 \%)\end{array}$ & $\begin{array}{c}32.95 \\
(42.29 \%) \\
\end{array}$ & $\begin{array}{c}8.36 \\
(10.72 \%)\end{array}$ & $\begin{array}{c}17.83 \\
(22.88 \%)\end{array}$ & $\begin{array}{c}28.31 \\
(36.33 \%)\end{array}$ & $\begin{array}{c}12.43 \\
(15.95 \%) \\
\end{array}$ & $\begin{array}{c}-13.43 \\
(-17.24 \%)\end{array}$ \\
\hline $0.35 \%$ transaction costs & $\begin{array}{c}26.43 \\
(33.88 \%) \\
\end{array}$ & $\begin{array}{c}27.36 \\
(35.06 \%) \\
\end{array}$ & $\begin{array}{c}1.65 \\
(2.11 \%) \\
\end{array}$ & $\begin{array}{c}12.86 \\
(16.48 \%) \\
\end{array}$ & $\begin{array}{c}25.35 \\
(32.49 \%) \\
\end{array}$ & $\begin{array}{c}8.77 \\
(11.24 \%) \\
\end{array}$ & $\begin{array}{c}-13.65 \\
(-17.49 \%) \\
\end{array}$ \\
\hline $\begin{array}{l}\text { No. of times of buying (or selling) } \\
\text { the stock for Strategy } 2\end{array}$ & 25 & 21 & 27 & 20 & 13 & 14 & \\
\hline \multicolumn{8}{|c|}{ Stock no. 83} \\
\hline No transaction costs & $\begin{array}{c}3.49 \\
(50.19 \%)\end{array}$ & $\begin{array}{c}5.02 \\
(72.24 \%) \\
\end{array}$ & $\begin{array}{c}10.23 \\
(147.03 \%)\end{array}$ & $\begin{array}{c}5.80 \\
(83.38 \%)\end{array}$ & $\begin{array}{c}7.62 \\
(109.55 \%)\end{array}$ & $\begin{array}{c}5.65 \\
(81.28 \%)\end{array}$ & $\begin{array}{c}0.34 \\
(4.83 \%)\end{array}$ \\
\hline $0.1 \%$ transaction costs & $\begin{array}{c}2.79 \\
(40.09 \%)\end{array}$ & $\begin{array}{c}4.61 \\
(66.20 \%)\end{array}$ & $\begin{array}{c}10.12 \\
(145.34 \%)\end{array}$ & $\begin{array}{c}5.53 \\
(79.48 \%) \\
\end{array}$ & $\begin{array}{c}7.38 \\
(105.99 \%)\end{array}$ & $\begin{array}{c}5.37 \\
(77.16 \%) \\
\end{array}$ & $\begin{array}{c}0.32 \\
(4.62 \%)\end{array}$ \\
\hline $0.2 \%$ transaction costs & $\begin{array}{c}2.09 \\
(30.01 \%)\end{array}$ & $\begin{array}{c}4.19 \\
(60.17 \%)\end{array}$ & $\begin{array}{c}10.01 \\
(143.65 \%)\end{array}$ & $\begin{array}{c}5.27 \\
(75.58 \%) \\
\end{array}$ & $\begin{array}{c}7.14 \\
(102.44 \%)\end{array}$ & $\begin{array}{c}5.09 \\
(73.05 \%)\end{array}$ & $\begin{array}{c}0.31 \\
(4.41 \%)\end{array}$ \\
\hline $0.35 \%$ transaction costs & $\begin{array}{c}1.04 \\
(14.93 \%)\end{array}$ & $\begin{array}{c}3.57 \\
(51.15 \%)\end{array}$ & $\begin{array}{c}9.85 \\
(141.13 \%)\end{array}$ & $\begin{array}{c}4.87 \\
(69.75 \%)\end{array}$ & $\begin{array}{c}6.78 \\
(97.13 \%)\end{array}$ & $\begin{array}{c}4.67 \\
(66.91 \%) \\
\end{array}$ & $\begin{array}{c}0.29 \\
(4.10 \%)\end{array}$ \\
\hline $\begin{array}{l}\text { No. of times of buying (or selling) } \\
\text { the stock for Strategy } 2\end{array}$ & 28 & 19 & 5 & 8 & 7 & 8 & \\
\hline \multicolumn{8}{|c|}{ Stock no. 101} \\
\hline No transaction costs & $\begin{array}{c}-3.43 \\
(-28.58 \%)\end{array}$ & $\begin{array}{c}10.27 \\
(85.58 \%)\end{array}$ & $\begin{array}{c}10.20 \\
(85.00 \%)\end{array}$ & $\begin{array}{c}11.22 \\
(93.50 \%)\end{array}$ & $\begin{array}{c}9.45 \\
(78.75 \%)\end{array}$ & $\begin{array}{c}12.35 \\
(102.92 \%)\end{array}$ & $\begin{array}{c}4.84 \\
(40.33 \%)\end{array}$ \\
\hline $0.1 \%$ transaction costs & $\begin{array}{c}-4.96 \\
(-41.31 \%)\end{array}$ & $\begin{array}{c}9.42 \\
(78.38 \%)\end{array}$ & $\begin{array}{c}9.54 \\
(79.39 \%) \\
\end{array}$ & $\begin{array}{c}10.65 \\
(88.70 \%)\end{array}$ & $\begin{array}{c}8.60 \\
(71.62 \%) \\
\end{array}$ & $\begin{array}{c}11.94 \\
(99.38 \%)\end{array}$ & $\begin{array}{c}4.81 \\
(40.05 \%) \\
\end{array}$ \\
\hline $0.2 \%$ transaction costs & $\begin{array}{c}-6.49 \\
(-54.00 \%)\end{array}$ & $\begin{array}{c}8.56 \\
(71.20 \%) \\
\end{array}$ & $\begin{array}{c}8.87 \\
(73.79 \%)\end{array}$ & $\begin{array}{c}10.09 \\
(83.90 \%)\end{array}$ & $\begin{array}{c}7.76 \\
(64.50 \%)\end{array}$ & $\begin{array}{c}11.53 \\
(95.85 \%)\end{array}$ & $\begin{array}{c}4.78 \\
(39.77 \%)\end{array}$ \\
\hline $0.35 \%$ transaction costs & $\begin{array}{c}-8.79 \\
(-73.00 \%)\end{array}$ & $\begin{array}{c}7.28 \\
(60.45 \%)\end{array}$ & $\begin{array}{c}7.88 \\
(65.41 \%)\end{array}$ & $\begin{array}{c}9.24 \\
(76.73 \%)\end{array}$ & $\begin{array}{c}6.48 \\
(53.85 \%)\end{array}$ & $\begin{array}{c}10.91 \\
(90.58 \%)\end{array}$ & $\begin{array}{c}4.74 \\
(39.35 \%)\end{array}$ \\
\hline $\begin{array}{l}\text { No. of times of buying (or selling) } \\
\text { the stock for Strategy } 2\end{array}$ & 39 & 25 & 19 & 15 & 23 & 42 & \\
\hline \multicolumn{8}{|c|}{ Stock no. 388} \\
\hline No transaction costs & $\begin{array}{c}175.50 \\
(843.75 \%)\end{array}$ & $\begin{array}{c}152.60 \\
(733.65) \%\end{array}$ & $\begin{array}{c}121.60 \\
(584.62 \%)\end{array}$ & $\begin{array}{c}125.60 \\
(603.85 \%)\end{array}$ & $\begin{array}{c}117.80 \\
(604.10 \%)\end{array}$ & $\begin{array}{c}101.55 \\
(488.22 \%)\end{array}$ & $\begin{array}{c}52.80 \\
(253.85 \%)\end{array}$ \\
\hline $0.1 \%$ transaction costs & $\begin{array}{c}173.67 \\
(834.09 \%)\end{array}$ & $\begin{array}{c}151.52 \\
(727.75 \%)\end{array}$ & $\begin{array}{c}121.04 \\
(581.34 \%)\end{array}$ & $\begin{array}{c}124.49 \\
(597.93 \%)\end{array}$ & $\begin{array}{c}117.09 \\
(599.87 \%)\end{array}$ & $\begin{array}{c}101.12 \\
(485.64 \%)\end{array}$ & $\begin{array}{c}52.71 \\
(253.14 \%)\end{array}$ \\
\hline $0.2 \%$ transaction costs & $\begin{array}{c}171.83 \\
(824.46 \%)\end{array}$ & $\begin{array}{c}150.45 \\
(721.86 \%)\end{array}$ & $\begin{array}{c}120.48 \\
(578.06 \%)\end{array}$ & $\begin{array}{c}123.39 \\
(592.03 \%)\end{array}$ & $\begin{array}{c}116.38 \\
(595.65 \%)\end{array}$ & $\begin{array}{c}100.68 \\
(483.07 \%)\end{array}$ & $\begin{array}{c}52.61 \\
(252.43 \%)\end{array}$ \\
\hline $0.35 \%$ transaction costs & $\begin{array}{c}169.08 \\
(810.04 \%)\end{array}$ & $\begin{array}{c}148.83 \\
(713.05 \%) \\
\end{array}$ & $\begin{array}{c}119.64 \\
(573.17 \%) \\
\end{array}$ & $\begin{array}{c}121.73 \\
(583.19 \%)\end{array}$ & $\begin{array}{c}115.32 \\
(589.33 \%) \\
\end{array}$ & $\begin{array}{c}100.03 \\
(479.23 \%)\end{array}$ & $\begin{array}{c}52.47 \\
(251.38 \%) \\
\end{array}$ \\
\hline $\begin{array}{l}\text { No. of times of buying (or selling) } \\
\text { the stock for Strategy } 2\end{array}$ & 12 & 9 & 5 & 4 & 3 & 3 & \\
\hline
\end{tabular}


End of Table 5

\begin{tabular}{|c|c|c|c|c|c|c|c|}
\hline Moving-window size & 40 & 80 & 120 & 160 & 200 & 240 & buy-and-hold \\
\hline \multicolumn{8}{|c|}{ Stock no. 688} \\
\hline No transaction costs & $\begin{array}{c}8.11 \\
(452.09 \%)\end{array}$ & $\begin{array}{c}8.73 \\
(486.89 \%) \\
\end{array}$ & $\begin{array}{c}12.90 \\
(719.69 \%)\end{array}$ & $\begin{array}{c}12.42 \\
(692.64 \%)\end{array}$ & $\begin{array}{c}11.36 \\
(633.58 \%) \\
\end{array}$ & $\begin{array}{c}9.09 \\
(507.14 \%)\end{array}$ & $\begin{array}{c}8.86 \\
(494.03 \%) \\
\end{array}$ \\
\hline $0.1 \%$ transaction costs & $\begin{array}{c}7.66 \\
(426.87 \%)\end{array}$ & $\begin{array}{c}8.40 \\
(468.23 \%)\end{array}$ & $\begin{array}{c}12.70 \\
(707.88 \%)\end{array}$ & $\begin{array}{c}12.39 \\
(690.48 \%)\end{array}$ & $\begin{array}{c}11.24 \\
(626.29 \%)\end{array}$ & $\begin{array}{c}9.01 \\
(502.14 \%)\end{array}$ & $\begin{array}{c}8.85 \\
(492.85 \%)\end{array}$ \\
\hline $0.2 \%$ transaction costs & $\begin{array}{c}7.22 \\
(401.70 \%)\end{array}$ & $\begin{array}{c}8.08 \\
(449.60 \%)\end{array}$ & $\begin{array}{c}12.51 \\
(696.09 \%)\end{array}$ & $\begin{array}{c}12.37 \\
(688.33 \%)\end{array}$ & $\begin{array}{c}11.12 \\
(619.02 \%)\end{array}$ & $\begin{array}{c}8.93 \\
(497.16 \%)\end{array}$ & $\begin{array}{c}8.83 \\
(491.66 \%)\end{array}$ \\
\hline $0.35 \%$ transaction costs & $\begin{array}{c}6.55 \\
(364.04 \%) \\
\end{array}$ & $\begin{array}{c}7.59 \\
(421.72 \%) \\
\end{array}$ & $\begin{array}{c}12.21 \\
(678.45 \%) \\
\end{array}$ & $\begin{array}{c}12.33 \\
(685.10 \%) \\
\end{array}$ & $\begin{array}{c}10.94 \\
(608.13 \%)\end{array}$ & $\begin{array}{c}8.81 \\
(489.70 \%) \\
\end{array}$ & $\begin{array}{c}8.81 \\
(489.89 \%) \\
\end{array}$ \\
\hline $\begin{array}{l}\text { No. of times of buying (or selling) } \\
\text { the stock for Strategy } 2\end{array}$ & 23 & 19 & 11 & 4 & 12 & 8 & \\
\hline \multicolumn{8}{|c|}{ Stock no. 857} \\
\hline No transaction costs & $\begin{array}{c}3.65 \\
(84.28 \%)\end{array}$ & $\begin{array}{c}4.23 \\
(101.93 \%)\end{array}$ & $\begin{array}{c}6.95 \\
(167.47 \%)\end{array}$ & $\begin{array}{c}3.24 \\
(78.07 \%)\end{array}$ & $\begin{array}{c}5.64 \\
(137.56 \%)\end{array}$ & $\begin{array}{c}2.60 \\
(61.90 \%)\end{array}$ & $\begin{array}{c}2.64 \\
(63.61 \%)\end{array}$ \\
\hline $0.1 \%$ transaction costs & $\begin{array}{c}3.20 \\
(73.91 \%)\end{array}$ & $\begin{array}{c}3.91 \\
(94.20 \%) \\
\end{array}$ & $\begin{array}{c}6.83 \\
(164.31 \%)\end{array}$ & $\begin{array}{c}3.03 \\
(73.00 \%)\end{array}$ & $\begin{array}{c}5.55 \\
(135.12 \%)\end{array}$ & $\begin{array}{c}2.38 \\
(56.64 \%)\end{array}$ & $\begin{array}{c}2.63 \\
(63.29 \%) \\
\end{array}$ \\
\hline $0.2 \%$ transaction costs & $\begin{array}{c}2.75 \\
(63.56 \%) \\
\end{array}$ & $\begin{array}{c}3.60 \\
(86.49 \%)\end{array}$ & $\begin{array}{c}6.70 \\
(161.16 \%)\end{array}$ & $\begin{array}{c}2.83 \\
(67.94 \%)\end{array}$ & $\begin{array}{c}5.45 \\
(132.68 \%) \\
\end{array}$ & $\begin{array}{c}2.16 \\
(51.38 \%) \\
\end{array}$ & $\begin{array}{c}2.62 \\
(62.96 \%)\end{array}$ \\
\hline $0.35 \%$ transaction costs & $\begin{array}{c}2.09 \\
(48.07 \%) \\
\end{array}$ & $\begin{array}{c}3.12 \\
(74.94 \%) \\
\end{array}$ & $\begin{array}{c}6.52 \\
(156.44 \%) \\
\end{array}$ & $\begin{array}{c}2.51 \\
(60.37 \%) \\
\end{array}$ & $\begin{array}{c}5.31 \\
(129.02 \%) \\
\end{array}$ & $\begin{array}{c}1.83 \\
(43.52 \%) \\
\end{array}$ & $\begin{array}{c}2.60 \\
(62.47 \%) \\
\end{array}$ \\
\hline $\begin{array}{l}\text { No. of times of buying (or selling) } \\
\text { the stock for Strategy } 2\end{array}$ & 25 & 18 & 6 & 11 & 5 & 12 & \\
\hline \multicolumn{8}{|c|}{ Stock no. 883} \\
\hline No transaction costs & $\begin{array}{c}3.84 \\
(91.98 \%)\end{array}$ & $\begin{array}{c}0.65 \\
(15.69 \%)\end{array}$ & $\begin{array}{c}2.74 \\
(65.51 \%)\end{array}$ & $\begin{array}{c}8.16 \\
(195.33 \%)\end{array}$ & $\begin{array}{c}7.77 \\
(185.99 \%)\end{array}$ & $\begin{array}{c}6.57 \\
(157.25 \%)\end{array}$ & $\begin{array}{c}3.07 \\
(73.41 \%)\end{array}$ \\
\hline $0.1 \%$ transaction costs & $\begin{array}{c}3.26 \\
(78.04 \%)\end{array}$ & $\begin{array}{c}0.23 \\
(5.46 \%) \\
\end{array}$ & $\begin{array}{c}2.36 \\
(56.40 \%)\end{array}$ & $\begin{array}{c}7.93 \\
(189.76 \%)\end{array}$ & $\begin{array}{c}7.63 \\
(182.67 \%)\end{array}$ & $\begin{array}{c}6.41 \\
(153.46 \%)\end{array}$ & $\begin{array}{c}3.05 \\
(73.07 \%) \\
\end{array}$ \\
\hline $0.2 \%$ transaction costs & $\begin{array}{c}2.68 \\
(64.13 \%) \\
\end{array}$ & $\begin{array}{c}-0.20 \\
(-4.74 \%) \\
\end{array}$ & $\begin{array}{c}1.98 \\
(47.31 \%) \\
\end{array}$ & $\begin{array}{c}7.71 \\
(184.20 \%) \\
\end{array}$ & $\begin{array}{c}7.50 \\
(179.37 \%) \\
\end{array}$ & $\begin{array}{c}6.26 \\
(149.68 \%) \\
\end{array}$ & $\begin{array}{c}3.04 \\
(72.72 \%) \\
\end{array}$ \\
\hline $0.35 \%$ transaction costs & $\begin{array}{c}1.82 \\
(43.33 \%)\end{array}$ & $\begin{array}{c}-0.84 \\
(-20.01 \%) \\
\end{array}$ & $\begin{array}{c}1.41 \\
(33.70 \%)\end{array}$ & $\begin{array}{c}7.37 \\
(175.88 \%) \\
\end{array}$ & $\begin{array}{c}7.31 \\
(174.42 \%) \\
\end{array}$ & $\begin{array}{c}6.03 \\
(144.03 \%) \\
\end{array}$ & $\begin{array}{c}3.03 \\
(72.20 \%) \\
\end{array}$ \\
\hline $\begin{array}{l}\text { No. of times of buying (or selling) } \\
\text { the stock for Strategy } 2\end{array}$ & 32 & 30 & 26 & 15 & 10 & 10 & \\
\hline \multicolumn{8}{|c|}{ Stock no. 941} \\
\hline No transaction costs & $\begin{array}{c}65.15 \\
(247.25 \%)\end{array}$ & $\begin{array}{c}51.20 \\
(194.31 \%)\end{array}$ & $\begin{array}{c}83.45 \\
(316.70 \%)\end{array}$ & $\begin{array}{c}98.75 \\
(374.76 \%)\end{array}$ & $\begin{array}{c}80.20 \\
(304.36 \%)\end{array}$ & $\begin{array}{c}67.90 \\
(271.60 \%)\end{array}$ & $\begin{array}{c}51.45 \\
(195.26 \%)\end{array}$ \\
\hline $0.1 \%$ transaction costs & $\begin{array}{c}61.15 \\
(231.85 \%) \\
\end{array}$ & $\begin{array}{c}49.33 \\
(187.02 \%)\end{array}$ & $\begin{array}{c}83.24 \\
(315.57 \%) \\
\end{array}$ & $\begin{array}{c}98.60 \\
(373.81 \%)\end{array}$ & $\begin{array}{c}79.92 \\
(303.01 \%) \\
\end{array}$ & $\begin{array}{c}67.58 \\
(270.04 \%) \\
\end{array}$ & $\begin{array}{c}51.35 \\
(194.67 \%)\end{array}$ \\
\hline $0.2 \%$ transaction costs & $\begin{array}{c}57.16 \\
(216.48 \%)\end{array}$ & $\begin{array}{c}47.46 \\
(179.76 \%)\end{array}$ & $\begin{array}{c}83.02 \\
(314.44 \%)\end{array}$ & $\begin{array}{c}98.45 \\
(372.87 \%)\end{array}$ & $\begin{array}{c}79.65 \\
(301.65 \%)\end{array}$ & $\begin{array}{c}67.25 \\
(268.48 \%)\end{array}$ & $\begin{array}{c}51.24 \\
(194.08 \%)\end{array}$ \\
\hline $0.35 \%$ transaction costs & $\begin{array}{c}51.16 \\
(193.48 \%)\end{array}$ & $\begin{array}{c}44.66 \\
(168.88 \%)\end{array}$ & $\begin{array}{c}82.70 \\
(312.75 \%)\end{array}$ & $\begin{array}{c}98.22 \\
(371.45 \%)\end{array}$ & $\begin{array}{c}79.23 \\
(299.63 \%)\end{array}$ & $\begin{array}{c}66.77 \\
(266.15 \%)\end{array}$ & $\begin{array}{c}51.09 \\
193.20 \%\end{array}$ \\
\hline $\begin{array}{l}\text { No. of times of buying (or selling) } \\
\text { the stock for Strategy } 2\end{array}$ & 35 & 16 & 2 & 1 & 4 & 2 & \\
\hline \multicolumn{8}{|c|}{ Stock no. 1109} \\
\hline No transaction costs & $\begin{array}{c}4.26 \\
(322.73 \%)\end{array}$ & $\begin{array}{c}7.83 \\
(592.80 \%)\end{array}$ & $\begin{array}{c}11.75 \\
(889.77 \%)\end{array}$ & $\begin{array}{c}9.94 \\
(752.65 \%)\end{array}$ & $\begin{array}{c}8.71 \\
(670.00 \%)\end{array}$ & $\begin{array}{c}8.67 \\
(501.16 \%)\end{array}$ & $\begin{array}{c}8.18 \\
(619.70 \%)\end{array}$ \\
\hline $0.1 \%$ transaction costs & $\begin{array}{c}3.86 \\
(292.05 \%)\end{array}$ & $\begin{array}{c}7.57 \\
(573.20 \%)\end{array}$ & $\begin{array}{c}11.59 \\
(877.09 \%)\end{array}$ & $\begin{array}{c}9.75 \\
(738.20 \%)\end{array}$ & $\begin{array}{c}8.56 \\
(657.80 \%)\end{array}$ & $\begin{array}{c}8.59 \\
(495.75 \%)\end{array}$ & $\begin{array}{c}8.17 \\
(618.26 \%)\end{array}$ \\
\hline $0.2 \%$ transaction costs & $\begin{array}{c}3.46 \\
(261.43 \%) \\
\end{array}$ & $\begin{array}{c}7.32 \\
(553.64 \%) \\
\end{array}$ & $\begin{array}{c}11.43 \\
(864.44 \%)\end{array}$ & $\begin{array}{c}9.57 \\
(723.77 \%) \\
\end{array}$ & $\begin{array}{c}8.41 \\
(645.63 \%) \\
\end{array}$ & $\begin{array}{c}8.50 \\
(490.36 \%) \\
\end{array}$ & $\begin{array}{c}8.16 \\
(616.82 \%) \\
\end{array}$ \\
\hline $0.35 \%$ transaction costs & $\begin{array}{c}2.86 \\
(215.63 \%) \\
\end{array}$ & $\begin{array}{c}6.95 \\
(524.36 \%) \\
\end{array}$ & $\begin{array}{c}11.20 \\
(845.50 \%) \\
\end{array}$ & $\begin{array}{c}9.30 \\
(702.19 \%) \\
\end{array}$ & $\begin{array}{c}8.19 \\
(627.42 \%) \\
\end{array}$ & $\begin{array}{c}8.37 \\
(482.29 \%) \\
\end{array}$ & $\begin{array}{c}8.14 \\
(614.68 \%) \\
\end{array}$ \\
\hline $\begin{array}{l}\text { No. of times of buying (or selling) } \\
\text { the stock for Strategy } 2\end{array}$ & 23 & 14 & 14 & 10 & 7 & 4 & \\
\hline \multicolumn{8}{|c|}{ Stock no. 2628} \\
\hline No transaction costs & $\begin{array}{c}23.10 \\
(444.23 \%)\end{array}$ & $\begin{array}{c}30.60 \\
(588.46 \%)\end{array}$ & $\begin{array}{c}21.20 \\
(407.69 \%)\end{array}$ & $\begin{array}{c}22.25 \\
(427.88 \%)\end{array}$ & $\begin{array}{c}22.10 \\
(425.00 \%)\end{array}$ & $\begin{array}{c}16.95 \\
(316.82 \%)\end{array}$ & $\begin{array}{c}18.35 \\
(352.88 \%)\end{array}$ \\
\hline $0.1 \%$ transaction costs & $\begin{array}{c}22.27 \\
(427.82 \%)\end{array}$ & $\begin{array}{c}30.05 \\
(577.26 \%)\end{array}$ & $\begin{array}{c}20.80 \\
(399.68 \%)\end{array}$ & $\begin{array}{c}22.16 \\
(425.82 \%)\end{array}$ & $\begin{array}{c}21.78 \\
(418.43 \%)\end{array}$ & $\begin{array}{c}16.67 \\
(311.22 \%)\end{array}$ & $\begin{array}{c}18.32 \\
(351.98 \%)\end{array}$ \\
\hline $0.2 \%$ transaction costs & 21.44 & 29.50 & 20.41 & 22.08 & 21.46 & 16.38 & 18.29 \\
\hline & $(411.45 \%)$ & $(566.09 \%)$ & $(391.68 \%)$ & $(423.75 \%)$ & $(411.88 \%)$ & $(305.64 \%)$ & $(351.08 \%)$ \\
\hline $0.35 \%$ transaction costs & $\begin{array}{c}20.19 \\
(386.94 \%)\end{array}$ & $\begin{array}{c}28.67 \\
(549.36 \%) \\
\end{array}$ & $\begin{array}{c}19.81 \\
(379.72 \%)\end{array}$ & $\begin{array}{c}21.95 \\
(420.66 \%)\end{array}$ & $\begin{array}{c}20.98 \\
(402.07 \%) \\
\end{array}$ & $\begin{array}{c}15.96 \\
(297.28 \%)\end{array}$ & $\begin{array}{c}18.25 \\
(349.73 \%)\end{array}$ \\
\hline $\begin{array}{l}\text { No. of times of buying (or selling) } \\
\text { the stock for Strategy } 2\end{array}$ & 28 & 19 & 12 & 6 & 8 & 7 & \\
\hline
\end{tabular}


Table 6. Comparison between the profits of Strategy 3 and "buy-and-hold" (the red entries indicate that Strategy 3 beats "buy-and-hold", while the numbers in the brackets indicate the percentage profits)

\begin{tabular}{|c|c|c|c|c|c|c|c|}
\hline Moving-window size & 40 & 80 & 120 & 160 & 200 & 240 & buy-and-hold \\
\hline \multicolumn{8}{|c|}{ Stock no. 5} \\
\hline No transaction costs & $\begin{array}{c}-0.32 \\
(-0.26 \%)\end{array}$ & $\begin{array}{c}22.58 \\
(18.33 \%)\end{array}$ & $\begin{array}{c}-24.80 \\
(-20.13 \%)\end{array}$ & $\begin{array}{c}-14.38 \\
(-11.68 \%)\end{array}$ & $\begin{array}{c}-5.23 \\
(-4.25 \%)\end{array}$ & $\begin{array}{c}-35.24 \\
(-28.61 \%)\end{array}$ & $\begin{array}{c}-41.86 \\
(-33.99 \%)\end{array}$ \\
\hline $0.1 \%$ transaction costs & $\begin{array}{c}-14.71 \\
(-11.93 \%)\end{array}$ & $\begin{array}{c}13.85 \\
(11.24 \%)\end{array}$ & $\begin{array}{c}-35.80 \\
(-29.04 \%)\end{array}$ & $\begin{array}{c}-21.50 \\
(-17.44 \%)\end{array}$ & $\begin{array}{c}-9.66 \\
(-7.84 \%)\end{array}$ & $\begin{array}{c}-40.67 \\
(-32.99 \%)\end{array}$ & $\begin{array}{c}-42.06 \\
(-34.12 \%)\end{array}$ \\
\hline $0.2 \%$ transaction costs & $\begin{array}{c}-29.11 \\
(-23.59 \%)\end{array}$ & $\begin{array}{c}5.13 \\
(4.15 \%)\end{array}$ & $\begin{array}{c}-46.81 \\
(-37.93 \%)\end{array}$ & $\begin{array}{c}-28.61 \\
(-23.18 \%)\end{array}$ & $\begin{array}{c}-14.09 \\
(-11.41 \%)\end{array}$ & $\begin{array}{c}-46.10 \\
(-37.36 \%)\end{array}$ & $\begin{array}{c}-42.27 \\
(-34.25 \%)\end{array}$ \\
\hline $0.35 \%$ transaction costs & $\begin{array}{c}-50.70 \\
(-41.02 \%)\end{array}$ & $\begin{array}{c}-7.96 \\
(-6.44 \%)\end{array}$ & $\begin{array}{c}-63.31 \\
(-51.23 \%)\end{array}$ & $\begin{array}{c}-39.28 \\
(-31.78 \%)\end{array}$ & $\begin{array}{c}-20.73 \\
(-16.77 \%)\end{array}$ & $\begin{array}{c}-54.24 \\
(-43.89 \%)\end{array}$ & $\begin{array}{c}-42.57 \\
(-34.45 \%)\end{array}$ \\
\hline $\begin{array}{l}\text { No. of times of buying (or selling) } \\
\text { the stock for Strategy } 3\end{array}$ & 71 & 43 & 52 & 36 & 23 & 28 & \\
\hline \multicolumn{8}{|c|}{ Stock no. 12} \\
\hline No transaction costs & $\begin{array}{c}18.03 \\
(59.40 \%)\end{array}$ & $\begin{array}{c}20.93 \\
(68.95 \%)\end{array}$ & $\begin{array}{c}14.12 \\
(46.53 \%)\end{array}$ & $\begin{array}{c}16.08 \\
(52.97 \%)\end{array}$ & $\begin{array}{c}0.04 \\
(0.14 \%)\end{array}$ & $\begin{array}{c}0.38 \\
(1.42 \%)\end{array}$ & $\begin{array}{c}10.74 \\
(35.40 \%)\end{array}$ \\
\hline $0.1 \%$ transaction costs & $\begin{array}{c}13.86 \\
(45.61 \%)\end{array}$ & $\begin{array}{c}18.10 \\
(59.59 \%)\end{array}$ & $\begin{array}{c}11.54 \\
(38.00 \%)\end{array}$ & $\begin{array}{c}13.91 \\
(45.77 \%)\end{array}$ & $\begin{array}{c}-2.79 \\
(-9.17 \%)\end{array}$ & $\begin{array}{c}-1.94 \\
(-7.32 \%)\end{array}$ & $\begin{array}{c}10.67 \\
(35.13 \%)\end{array}$ \\
\hline $0.2 \%$ transaction costs & $\begin{array}{c}9.69 \\
(31.85 \%)\end{array}$ & $\begin{array}{c}15.28 \\
(50.24 \%)\end{array}$ & $\begin{array}{c}8.97 \\
(29.48 \%)\end{array}$ & $\begin{array}{c}11.74 \\
(38.59 \%)\end{array}$ & $\begin{array}{c}-5.62 \\
(-18.47 \%)\end{array}$ & $\begin{array}{c}-4.25 \\
(-16.03 \%)\end{array}$ & $\begin{array}{c}10.60 \\
(34.86 \%)\end{array}$ \\
\hline $0.35 \%$ transaction costs & $\begin{array}{c}3.43 \\
(11.26 \%)\end{array}$ & $\begin{array}{c}11.05 \\
(36.26 \%)\end{array}$ & $\begin{array}{c}5.10 \\
(16.73 \%)\end{array}$ & $\begin{array}{c}8.48 \\
(27.84 \%)\end{array}$ & $\begin{array}{c}-9.86 \\
(-32.38 \%)\end{array}$ & $\begin{array}{c}-7.72 \\
(-29.08 \%)\end{array}$ & $\begin{array}{c}10.49 \\
(34.45 \%)\end{array}$ \\
\hline $\begin{array}{l}\text { No. of times of buying (or selling) } \\
\text { the stock for Strategy } 3\end{array}$ & 58 & 41 & 39 & 33 & 40 & 33 & \\
\hline \multicolumn{8}{|c|}{ Stock no. 16} \\
\hline No transaction costs & $\begin{array}{c}53.65 \\
(69.00 \%)\end{array}$ & $\begin{array}{c}110.25 \\
(141.80 \%)\end{array}$ & $\begin{array}{c}38.65 \\
(49.71 \%)\end{array}$ & $\begin{array}{c}34.90 \\
(44.89 \%)\end{array}$ & $\begin{array}{c}23.20 \\
(29.84 \%)\end{array}$ & $\begin{array}{c}-6.20 \\
(-7.97 \%)\end{array}$ & $\begin{array}{c}38.45 \\
(49.45 \%)\end{array}$ \\
\hline $0.1 \%$ transaction costs & $\begin{array}{c}40.17 \\
(51.62 \%)\end{array}$ & $\begin{array}{c}102.67 \\
(131.92 \%)\end{array}$ & $\begin{array}{c}30.65 \\
(39.38 \%)\end{array}$ & $\begin{array}{c}26.89 \\
(34.55 \%)\end{array}$ & $\begin{array}{c}17.68 \\
(22.72 \%)\end{array}$ & $\begin{array}{c}-12.24 \\
(-15.73 \%)\end{array}$ & $\begin{array}{c}38.26 \\
(49.15 \%)\end{array}$ \\
\hline $0.2 \%$ transaction costs & $\begin{array}{c}26.70 \\
(34.27 \%)\end{array}$ & $\begin{array}{c}95.09 \\
(122.06 \%)\end{array}$ & $\begin{array}{c}22.65 \\
(29.07 \%)\end{array}$ & $\begin{array}{c}18.88 \\
(24.24 \%)\end{array}$ & $\begin{array}{c}12.17 \\
(15.62 \%)\end{array}$ & $\begin{array}{c}-18.29 \\
(-23.48 \%)\end{array}$ & $\begin{array}{c}38.06 \\
(48.86 \%) \\
\end{array}$ \\
\hline $0.35 \%$ transaction costs & $\begin{array}{c}6.49 \\
(8.31 \%)\end{array}$ & $\begin{array}{c}83.72 \\
(107.30 \%)\end{array}$ & $\begin{array}{c}10.65 \\
(13.65 \%)\end{array}$ & $\begin{array}{c}6.87 \\
(8.80 \%)\end{array}$ & $\begin{array}{c}3.90 \\
(4.99 \%)\end{array}$ & $\begin{array}{c}-27.36 \\
(-35.06 \%)\end{array}$ & $\begin{array}{c}37.77 \\
(48.41 \%)\end{array}$ \\
\hline $\begin{array}{l}\text { No. of times of buying (or selling) } \\
\text { the stock for Strategy } 3\end{array}$ & 66 & 39 & 43 & 41 & 29 & 30 & \\
\hline \multicolumn{8}{|c|}{ Stock no. 83} \\
\hline No transaction costs & $\begin{array}{c}5.17 \\
(74.26 \%)\end{array}$ & $\begin{array}{c}11.35 \\
(163.18 \%)\end{array}$ & $\begin{array}{c}10.32 \\
(148.43 \%)\end{array}$ & $\begin{array}{c}2.84 \\
(40.83 \%)\end{array}$ & $\begin{array}{c}4.35 \\
(62.56 \%)\end{array}$ & $\begin{array}{c}0.84 \\
(12.14 \%)\end{array}$ & $\begin{array}{c}6.985 \\
(100.43 \%)\end{array}$ \\
\hline $0.1 \%$ transaction costs & $\begin{array}{c}3.66 \\
(52.52 \%) \\
\end{array}$ & $\begin{array}{c}10.18 \\
(146.25 \%)\end{array}$ & $\begin{array}{c}9.61 \\
(138.07 \%) \\
\end{array}$ & $\begin{array}{c}1.83 \\
(26.28 \%) \\
\end{array}$ & $\begin{array}{c}3.49 \\
(50.17 \%) \\
\end{array}$ & $\begin{array}{c}0.00 \\
(-0.06 \%) \\
\end{array}$ & $\begin{array}{c}6.96 \\
(100.03 \%)\end{array}$ \\
\hline $0.2 \%$ transaction costs & $\begin{array}{c}2.15 \\
(30.82 \%)\end{array}$ & $\begin{array}{c}9.02 \\
(129.37 \%)\end{array}$ & $\begin{array}{c}8.90 \\
(127.74 \%)\end{array}$ & $\begin{array}{c}0.82 \\
(11.76 \%)\end{array}$ & $\begin{array}{c}2.63 \\
(37.80 \%)\end{array}$ & $\begin{array}{c}-0.85 \\
(-12.24 \%)\end{array}$ & $\begin{array}{c}6.94 \\
(99.63 \%)\end{array}$ \\
\hline $0.35 \%$ transaction costs & $\begin{array}{c}-0.11 \\
(-1.65 \%)\end{array}$ & $\begin{array}{c}7.27 \\
(104.09 \%)\end{array}$ & $\begin{array}{c}7.84 \\
(112.28 \%) \\
\end{array}$ & $\begin{array}{c}-0.70 \\
(-9.97 \%)\end{array}$ & $\begin{array}{c}1.35 \\
(19.30 \%)\end{array}$ & $\begin{array}{c}-2.13 \\
(-30.45 \%)\end{array}$ & $\begin{array}{c}6.91 \\
(99.03 \%)\end{array}$ \\
\hline $\begin{array}{l}\text { No. of times of buying (or selling) } \\
\text { the stock for Strategy } 3\end{array}$ & 60 & 48 & 29 & 37 & 31 & 30 & \\
\hline \multicolumn{8}{|c|}{ Stock no. 101} \\
\hline No transaction costs & $\begin{array}{c}-6.49 \\
(-54.08 \%)\end{array}$ & $\begin{array}{c}17.65 \\
(147.08 \%)\end{array}$ & $\begin{array}{c}22.34 \\
(186.17 \%) \\
\end{array}$ & $\begin{array}{c}9.32 \\
(77.67 \%)\end{array}$ & $\begin{array}{c}16.80 \\
(140.00 \%)\end{array}$ & $\begin{array}{c}16.40 \\
(136.67 \%)\end{array}$ & $\begin{array}{c}18.80 \\
(156.67 \%)\end{array}$ \\
\hline $0.1 \%$ transaction costs & $\begin{array}{c}-10.40 \\
(-86.55 \%)\end{array}$ & $\begin{array}{c}14.79 \\
(123.15 \%)\end{array}$ & $\begin{array}{c}20.60 \\
(171.46 \%) \\
\end{array}$ & $\begin{array}{c}7.60 \\
(63.30 \%) \\
\end{array}$ & $\begin{array}{c}15.12 \\
(125.87 \%)\end{array}$ & $\begin{array}{c}15.46 \\
(128.71 \%)\end{array}$ & $\begin{array}{c}18.76 \\
(156.15 \%)\end{array}$ \\
\hline $0.2 \%$ transaction costs & $\begin{array}{c}-14.30 \\
(-118.95 \%)\end{array}$ & $\begin{array}{c}11.93 \\
(99.26 \%)\end{array}$ & $\begin{array}{c}18.85 \\
(156.78 \%)\end{array}$ & $\begin{array}{c}5.89 \\
(48.97 \%)\end{array}$ & $\begin{array}{c}13.44 \\
(111.77 \%)\end{array}$ & $\begin{array}{c}14.52 \\
(120.78 \%)\end{array}$ & $\begin{array}{c}18.71 \\
(155.64 \%)\end{array}$ \\
\hline $0.35 \%$ transaction costs & $\begin{array}{c}-20.16 \\
(-167.43 \%)\end{array}$ & $\begin{array}{c}7.65 \\
(63.51 \%)\end{array}$ & $\begin{array}{c}16.24 \\
(134.82 \%)\end{array}$ & $\begin{array}{c}3.31 \\
(27.52 \%)\end{array}$ & $\begin{array}{c}10.92 \\
(90.68 \%)\end{array}$ & $\begin{array}{c}13.11 \\
(108.90 \%)\end{array}$ & $\begin{array}{c}18.65 \\
(154.88 \%)\end{array}$ \\
\hline $\begin{array}{l}\text { No. of times of buying (or selling) } \\
\text { the stock for Strategy } 3\end{array}$ & 82 & 60 & 39 & 35 & 38 & 22 & \\
\hline \multicolumn{8}{|c|}{ Stock no. 388} \\
\hline No transaction costs & $\begin{array}{c}271.55 \\
(1305.53 \%)\end{array}$ & $\begin{array}{c}288.30 \\
(1386.06 \%)\end{array}$ & $\begin{array}{c}201.30 \\
(967.79 \%)\end{array}$ & $\begin{array}{c}158.80 \\
(763.46 \%)\end{array}$ & $\begin{array}{c}121.30 \\
(622.05 \%)\end{array}$ & $\begin{array}{c}55.25 \\
(265.63 \%)\end{array}$ & $\begin{array}{c}111.10 \\
(534.13 \%)\end{array}$ \\
\hline $0.1 \%$ transaction costs & $\begin{array}{c}262.51 \\
(1260.79 \%)\end{array}$ & $\begin{array}{c}283.52 \\
(1361.72 \%)\end{array}$ & $\begin{array}{c}196.62 \\
(944.35 \%)\end{array}$ & $\begin{array}{c}155.72 \\
(747.93 \%)\end{array}$ & $\begin{array}{c}118.23 \\
(605.71 \%)\end{array}$ & $\begin{array}{c}53.01 \\
(254.61 \%)\end{array}$ & $\begin{array}{c}110.95 \\
(532.87 \%)\end{array}$ \\
\hline $0.2 \%$ transaction costs & $\begin{array}{c}253.46 \\
(1216.14 \%)\end{array}$ & $\begin{array}{c}278.74 \\
(1337.43 \%)\end{array}$ & $\begin{array}{c}191.94 \\
(920.96 \%)\end{array}$ & $\begin{array}{c}152.65 \\
(732.43 \%)\end{array}$ & $\begin{array}{c}115.16 \\
(589.39 \%)\end{array}$ & $\begin{array}{c}50.77 \\
(243.62 \%)\end{array}$ & $\begin{array}{c}110.79 \\
(531.60 \%)\end{array}$ \\
\hline $0.35 \%$ transaction costs & $\begin{array}{c}239.90 \\
(1149.33 \%)\end{array}$ & $\begin{array}{c}271.57 \\
(1301.09 \%) \\
\end{array}$ & $\begin{array}{c}184.92 \\
(885.95 \%)\end{array}$ & $\begin{array}{c}148.04 \\
(709.23 \%)\end{array}$ & $\begin{array}{c}110.56 \\
(564.98 \%)\end{array}$ & $\begin{array}{c}47.42 \\
(227.17 \%)\end{array}$ & $\begin{array}{c}110.57 \\
(529.71 \%)\end{array}$ \\
\hline $\begin{array}{l}\text { No. of times of buying (or selling) } \\
\text { the stock for Strategy } 3\end{array}$ & 40 & 22 & 19 & 12 & 12 & 10 & \\
\hline
\end{tabular}


End of Table 6

\begin{tabular}{|c|c|c|c|c|c|c|c|}
\hline Moving-window size & 40 & 80 & 120 & 160 & 200 & 240 & buy-and-hold \\
\hline \multicolumn{8}{|c|}{ Stock no. 688} \\
\hline No transaction costs & $\begin{array}{c}10.86 \\
(605.41 \%)\end{array}$ & $\begin{array}{c}14.20 \\
(791.97 \%)\end{array}$ & $\begin{array}{c}17.96 \\
(1001.90 \%)\end{array}$ & $\begin{array}{c}13.51 \\
(753.26 \%)\end{array}$ & $\begin{array}{c}9.09 \\
(506.86 \%)\end{array}$ & $\begin{array}{c}5.10 \\
(284.27 \%)\end{array}$ & $\begin{array}{c}21.03 \\
(1172.95 \%)\end{array}$ \\
\hline $0.1 \%$ transaction costs & $\begin{array}{c}8.87 \\
(494.21 \%) \\
\end{array}$ & $\begin{array}{c}12.70 \\
(707.75 \%)\end{array}$ & $\begin{array}{c}17.19 \\
(957.97 \%)\end{array}$ & $\begin{array}{c}12.89 \\
(717.93 \%)\end{array}$ & $\begin{array}{c}8.31 \\
(463.07 \%)\end{array}$ & $\begin{array}{c}4.12 \\
(229.73 \%)\end{array}$ & $\begin{array}{c}21.01 \\
(1170.41 \%)\end{array}$ \\
\hline $0.2 \%$ transaction costs & $\begin{array}{c}6.89 \\
(383.24 \%)\end{array}$ & $\begin{array}{c}11.21 \\
(623.71 \%)\end{array}$ & $\begin{array}{c}16.42 \\
(914.13 \%)\end{array}$ & $\begin{array}{c}12.26 \\
(682.68 \%)\end{array}$ & $\begin{array}{c}7.53 \\
(419.37 \%)\end{array}$ & $\begin{array}{c}3.15 \\
(175.30 \%)\end{array}$ & $\begin{array}{c}20.98 \\
(1167.87 \%)\end{array}$ \\
\hline $0.35 \%$ transaction costs & $\begin{array}{c}3.91 \\
(217.19 \%)\end{array}$ & $\begin{array}{c}8.96 \\
(497.95 \%)\end{array}$ & $\begin{array}{c}15.27 \\
(848.54 \%)\end{array}$ & $\begin{array}{c}11.33 \\
(629.92 \%)\end{array}$ & $\begin{array}{c}6.37 \\
(353.97 \%)\end{array}$ & $\begin{array}{c}1.69 \\
(93.85 \%)\end{array}$ & $\begin{array}{c}20.94 \\
(1164.07 \%)\end{array}$ \\
\hline $\begin{array}{l}\text { No. of times of buying (or selling) } \\
\text { the stock for Strategy } 3\end{array}$ & 72 & 57 & 29 & 23 & 32 & 35 & \\
\hline \multicolumn{8}{|c|}{ Stock no. 857} \\
\hline No transaction costs & $\begin{array}{c}4.19 \\
(96.76 \%)\end{array}$ & $\begin{array}{c}7.32 \\
(176.39 \%)\end{array}$ & $\begin{array}{c}8.01 \\
(193.01 \%)\end{array}$ & $\begin{array}{c}2.48 \\
(59.76 \%)\end{array}$ & $\begin{array}{c}5.22 \\
(127.32 \%)\end{array}$ & $\begin{array}{c}-0.19 \\
(-4.52 \%)\end{array}$ & $\begin{array}{c}6.83 \\
(164.58 \%)\end{array}$ \\
\hline $0.1 \%$ transaction costs & $\begin{array}{c}3.03 \\
(70.05 \%)\end{array}$ & $\begin{array}{c}6.62 \\
(159.40 \%)\end{array}$ & $\begin{array}{c}7.36 \\
(177.19 \%)\end{array}$ & $\begin{array}{c}1.96 \\
(47.12 \%)\end{array}$ & $\begin{array}{c}4.73 \\
(115.36 \%)\end{array}$ & $\begin{array}{c}-1.10 \\
(-26.07 \%)\end{array}$ & $\begin{array}{c}6.81 \\
(164.05 \%)\end{array}$ \\
\hline $0.2 \%$ transaction costs & $\begin{array}{c}1.88 \\
(43.40 \%) \\
\end{array}$ & $\begin{array}{c}5.92 \\
(142.45 \%)\end{array}$ & $\begin{array}{c}6.71 \\
(161.40 \%) \\
\end{array}$ & $\begin{array}{c}1.43 \\
(34.51 \%) \\
\end{array}$ & $\begin{array}{c}4.25 \\
(103.43 \%)\end{array}$ & $\begin{array}{c}-2.00 \\
(-47.58 \%)\end{array}$ & $\begin{array}{c}6.80 \\
(163.52 \%)\end{array}$ \\
\hline $0.35 \%$ transaction costs & $\begin{array}{c}0.15 \\
(3.51 \%) \\
\end{array}$ & $\begin{array}{c}4.88 \\
(117.08 \%) \\
\end{array}$ & $\begin{array}{c}5.74 \\
(137.78 \%) \\
\end{array}$ & $\begin{array}{c}0.65 \\
(15.64 \%)\end{array}$ & $\begin{array}{c}3.52 \\
(85.57 \%) \\
\end{array}$ & $\begin{array}{c}-3.36 \\
(-79.76 \%) \\
\end{array}$ & $\begin{array}{c}6.78 \\
(162.73 \%)\end{array}$ \\
\hline $\begin{array}{l}\text { No. of times of buying (or selling) } \\
\text { the stock for Strategy } 3\end{array}$ & 62 & 39 & 33 & 27 & 25 & 46 & \\
\hline \multicolumn{8}{|c|}{ Stock no. 883} \\
\hline No transaction costs & $\begin{array}{c}6.14 \\
(147.07 \%)\end{array}$ & $\begin{array}{c}9.91 \\
(237.25 \%)\end{array}$ & $\begin{array}{c}9.48 \\
(227.19 \%)\end{array}$ & $\begin{array}{c}8.34 \\
(199.64 \%)\end{array}$ & $\begin{array}{c}14.31 \\
(342.63 \%)\end{array}$ & $\begin{array}{c}11.25 \\
(269.34 \%)\end{array}$ & $\begin{array}{c}12.61 \\
(301.92 \%)\end{array}$ \\
\hline $0.1 \%$ transaction costs & $\begin{array}{c}4.53 \\
(108.30 \%)\end{array}$ & $\begin{array}{c}8.53 \\
(204.21 \%) \\
\end{array}$ & $\begin{array}{c}8.63 \\
(206.62 \%) \\
\end{array}$ & $\begin{array}{c}7.30 \\
(174.67 \%)\end{array}$ & $\begin{array}{c}13.91 \\
(332.82 \%)\end{array}$ & $\begin{array}{c}10.77 \\
(257.64 \%)\end{array}$ & $\begin{array}{c}12.58 \\
(301.11 \%)\end{array}$ \\
\hline $0.2 \%$ transaction costs & $\begin{array}{c}2.91 \\
(69.62 \%)\end{array}$ & $\begin{array}{c}7.16 \\
(171.23 \%)\end{array}$ & $\begin{array}{c}7.78 \\
(186.09 \%)\end{array}$ & $\begin{array}{c}6.26 \\
(149.75 \%) \\
\end{array}$ & $\begin{array}{c}13.51 \\
(323.03 \%)\end{array}$ & $\begin{array}{c}10.29 \\
(245.96 \%)\end{array}$ & $\begin{array}{c}12.56 \\
(300.31 \%)\end{array}$ \\
\hline $0.35 \%$ transaction costs & $\begin{array}{c}0.49 \\
(11.73 \%)\end{array}$ & $\begin{array}{c}5.11 \\
(121.90 \%)\end{array}$ & $\begin{array}{c}6.51 \\
(155.38 \%)\end{array}$ & $\begin{array}{c}4.71 \\
(112.46 \%)\end{array}$ & $\begin{array}{c}12.92 \\
(308.38 \%)\end{array}$ & $\begin{array}{c}9.57 \\
(228.48 \%)\end{array}$ & $\begin{array}{c}12.53 \\
(299.11 \%)\end{array}$ \\
\hline $\begin{array}{l}\text { No. of times of buying (or selling) } \\
\text { the stock for Strategy } 3\end{array}$ & 70 & 65 & 43 & 42 & 19 & 21 & \\
\hline \multicolumn{8}{|c|}{ Stock no. 941} \\
\hline No transaction costs & $\begin{array}{c}49.35 \\
(187.29 \%)\end{array}$ & $\begin{array}{c}38.25 \\
(145.16 \%)\end{array}$ & $\begin{array}{c}69.70 \\
(264.52 \%)\end{array}$ & $\begin{array}{c}84.05 \\
(318.98 \%) \\
\end{array}$ & $\begin{array}{c}53.45 \\
(202.85 \%)\end{array}$ & $\begin{array}{c}62.20 \\
(248.80 \%)\end{array}$ & $\begin{array}{c}63.90 \\
(242.50 \%)\end{array}$ \\
\hline $0.1 \%$ transaction costs & $\begin{array}{c}38.56 \\
(146.20 \%)\end{array}$ & $\begin{array}{c}30.76 \\
(116.60 \%)\end{array}$ & $\begin{array}{c}63.60 \\
(241.13 \%)\end{array}$ & $\begin{array}{c}78.74 \\
(298.52 \%)\end{array}$ & $\begin{array}{c}47.93 \\
(181.73 \%)\end{array}$ & $\begin{array}{c}56.78 \\
(226.88 \%)\end{array}$ & $\begin{array}{c}63.78 \\
(241.82 \%)\end{array}$ \\
\hline $0.2 \%$ transaction costs & $\begin{array}{c}27.78 \\
(105.20 \%)\end{array}$ & $\begin{array}{c}23.26 \\
(88.11 \%)\end{array}$ & $\begin{array}{c}57.50 \\
(217.79 \%)\end{array}$ & $\begin{array}{c}73.43 \\
(278.11 \%)\end{array}$ & $\begin{array}{c}42.42 \\
(160.65 \%)\end{array}$ & $\begin{array}{c}51.35 \\
(205.01 \%)\end{array}$ & $\begin{array}{c}63.67 \\
(241.14 \%)\end{array}$ \\
\hline $0.35 \%$ transaction costs & $\begin{array}{c}11.60 \\
(43.86 \%)\end{array}$ & $\begin{array}{c}12.02 \\
(45.46 \%)\end{array}$ & $\begin{array}{c}48.35 \\
(182.86 \%)\end{array}$ & $\begin{array}{c}65.46 \\
(247.57 \%)\end{array}$ & $\begin{array}{c}34.14 \\
(129.11 \%)\end{array}$ & $\begin{array}{c}43.22 \\
(172.28 \%)\end{array}$ & $\begin{array}{c}63.49 \\
(240.12 \%)\end{array}$ \\
\hline $\begin{array}{l}\text { No. of times of buying (or selling) } \\
\text { the stock for Strategy } 3\end{array}$ & 79 & 52 & 40 & 34 & 38 & 35 & \\
\hline \multicolumn{8}{|c|}{ Stock no. 1109} \\
\hline No transaction costs & $\begin{array}{c}10.91 \\
(826.52 \%)\end{array}$ & $\begin{array}{c}18.94 \\
(1434.47 \%)\end{array}$ & $\begin{array}{c}17.49 \\
(1324.62 \%)\end{array}$ & $\begin{array}{c}19.06 \\
(1443.56 \%)\end{array}$ & $\begin{array}{c}12.75 \\
(980.77 \%)\end{array}$ & $\begin{array}{c}9.67 \\
(558.96 \%)\end{array}$ & $\begin{array}{c}19.78 \\
(1498.48 \%)\end{array}$ \\
\hline $0.1 \%$ transaction costs & $\begin{array}{c}9.39 \\
(710.63 \%)\end{array}$ & $\begin{array}{c}17.74 \\
(1342.33 \%)\end{array}$ & $\begin{array}{c}16.63 \\
(1258.92 \%)\end{array}$ & $\begin{array}{c}18.50 \\
(1400.35 \%)\end{array}$ & $\begin{array}{c}12.11 \\
(930.48 \%)\end{array}$ & $\begin{array}{c}9.22 \\
(532.20 \%)\end{array}$ & $\begin{array}{c}19.76 \\
(1495.29 \%)\end{array}$ \\
\hline $0.2 \%$ transaction costs & $\begin{array}{c}7.87 \\
(594.98 \%)\end{array}$ & $\begin{array}{c}16.54 \\
(1250.38 \%)\end{array}$ & $\begin{array}{c}15.78 \\
(1193.34 \%)\end{array}$ & $\begin{array}{c}17.95 \\
(1357.22 \%)\end{array}$ & $\begin{array}{c}11.47 \\
(880.30 \%)\end{array}$ & $\begin{array}{c}8.76 \\
(505.50 \%)\end{array}$ & $\begin{array}{c}19.74 \\
(1492.10 \%)\end{array}$ \\
\hline $0.35 \%$ transaction costs & $\begin{array}{c}5.59 \\
(421.93 \%)\end{array}$ & $\begin{array}{c}14.74 \\
(1112.79 \%)\end{array}$ & $\begin{array}{c}14.51 \\
(1095.23 \%)\end{array}$ & $\begin{array}{c}17.12 \\
(1292.70 \%)\end{array}$ & $\begin{array}{c}10.50 \\
(805.20 \%)\end{array}$ & $\begin{array}{c}8.08 \\
(465.55 \%)\end{array}$ & $\begin{array}{c}19.70 \\
(1487.33 \%)\end{array}$ \\
\hline $\begin{array}{l}\text { No. of times of buying (or } \\
\text { selling) the stock for Strategy } 3\end{array}$ & 62 & 49 & 37 & 22 & 23 & 16 & \\
\hline \multicolumn{8}{|c|}{ Stock no. 2628} \\
\hline No transaction costs & $\begin{array}{c}21.47 \\
(412.88 \%)\end{array}$ & $\begin{array}{c}42.23 \\
(812.12 \%) \\
\end{array}$ & $\begin{array}{c}20.58 \\
(395.77 \%) \\
\end{array}$ & $\begin{array}{c}27.06 \\
(520.38 \%) \\
\end{array}$ & $\begin{array}{c}26.08 \\
(501.54 \%) \\
\end{array}$ & $\begin{array}{c}15.85 \\
(296.26 \%)\end{array}$ & $\begin{array}{c}20.10 \\
(386.54 \%)\end{array}$ \\
\hline $0.1 \%$ transaction costs & $\begin{array}{c}18.80 \\
(361.12 \%)\end{array}$ & $\begin{array}{c}40.52 \\
(778.52 \%)\end{array}$ & $\begin{array}{c}18.48 \\
(355.11 \%)\end{array}$ & $\begin{array}{c}26.17 \\
(502.70 \%)\end{array}$ & $\begin{array}{c}25.02 \\
(480.72 \%)\end{array}$ & $\begin{array}{c}14.95 \\
(279.23 \%)\end{array}$ & $\begin{array}{c}20.07 \\
(385.57 \%)\end{array}$ \\
\hline $0.2 \%$ transaction costs & $\begin{array}{c}16.12 \\
(309.45 \%)\end{array}$ & $\begin{array}{c}38.82 \\
(744.99 \%)\end{array}$ & $\begin{array}{c}16.39 \\
(314.54 \%)\end{array}$ & $\begin{array}{c}25.27 \\
(485.06 \%) \\
\end{array}$ & $\begin{array}{c}23.97 \\
(459.95 \%)\end{array}$ & $\begin{array}{c}14.06 \\
(262.24 \%)\end{array}$ & $\begin{array}{c}20.04 \\
(384.60 \%)\end{array}$ \\
\hline $0.35 \%$ transaction costs & $\begin{array}{c}12.11 \\
(232.14 \%)\end{array}$ & $\begin{array}{c}36.26 \\
(694.82 \%) \\
\end{array}$ & $\begin{array}{c}13.25 \\
(253.83 \%)\end{array}$ & $\begin{array}{c}23.93 \\
(458.65 \%) \\
\end{array}$ & $\begin{array}{c}22.38 \\
(428.86 \%) \\
\end{array}$ & $\begin{array}{c}12.71 \\
(236.81 \%)\end{array}$ & $\begin{array}{c}19.99 \\
(383.14 \%)\end{array}$ \\
\hline $\begin{array}{l}\text { No. of times of buying (or selling) } \\
\text { the stock for Strategy } 3\end{array}$ & 61 & 41 & 40 & 21 & 21 & 17 & \\
\hline
\end{tabular}


Tables 5 and 6 show that change in length of period affects the result significantly. When the ending date is set to be December 31, 2008, Strategy 2 outperforms "buy-andhold" overwhelmingly ( 238 out of 288 cases). In particular, for 4 of the stocks (stocks no. 12, 16, 83 and 388), Strategy 2 beats "buy-and-hold" for all cases, no matter how large the moving-window size is. The main reason is that most of the stocks yield much lower returns during the shortened period 2005-2008 than during the whole period of observation. This can be seen by comparing the profits of "buy-and-hold" of the stocks in Tables 3 and 5. As explained in Sub-sections 5.1 and 5.2, our strategy is more likely to outperform "buyand-hold" during downturns. This explains why Strategy 2 outperforms "buy-and-hold" overwhelmingly. In fact, it is the global financial crisis causing most stocks to fall sharply in 2008. For the 50 cases of which Strategy 2 underperforms "buy-and-hold", 44 of them are stocks of China enterprises, showing that Strategy 2 performs better on stocks of nonChina enterprises than on stocks of China enterprises. This is because the global financial crisis has a greater impact on non-China enterprises, which have a greater portion of business in Hong Kong and a smaller portion of business in China than China enterprises do. This causes stocks of non-China enterprises to yield lower returns than stocks of China enterprises during the shortened period 2005-2008. 3 of them even yield negative returns. Therefore, Strategy 2 is more likely to outperform "buy-and-hold" for stocks of non-China enterprises than for stocks of China enterprises.

However, when the ending date of the period is changed to December 31, 2012, Strategy 3 beats "buy-and-hold" for only 94 out of 288 cases, which is even fewer than 127 cases for Strategy 1. In particular, for stocks no. 688 and 1109, Strategy 3 underperforms "buy-and-hold" for all cases, no matter how large the moving-window size is. The main reason is that the Hong Kong stock market is on a rising trend in 2012. However, the stock market experiences a downturn from mid-2015 to early 2016. As a result, most of the stocks yield higher returns during the shortened period 2005-2012 than during the whole period of observation (compare the profits of "buy-and-hold" of the stocks in Tables 3 and 6). Since our strategy is more likely to underperform "buy-and-hold" during bull markets, Strategy 3 underperforms "buy-and-hold" for more cases than Strategy 1. From Tables 3 and 6, Strategy 3 outperforms "buy-and-hold" for more cases on 3 stocks only (stocks no. 12, 83 and 388). 2 of them (stocks no. 12 and 388) yield lower return during 2005-2012 than during the whole period. Again, Strategy 3 is more effective on nonChina enterprise stocks than on China enterprise stocks. In particular, the two stocks of which Strategy 3 underperforms "buy-and-hold" for all cases (stocks no. 688 and 1109) are stocks of Chinese property companies. This is because stock prices of China enterprises rise by a larger extent than those of non-China enterprises during the period in general. In particular, the Chinese property market boom causes the stock prices of the two Chinese property companies to rise sharply.

Then we find the optimal moving-window size of Strategies 2 and 3 for each stock, under $0 \%, 0.1 \%, 0.2 \%$ and $0.35 \%$ transaction costs. The Tables 7 and 8 shows the optimal moving-window sizes of Strategies 2 and 3 for the 12 stocks under the four different amounts of transaction costs (the cases of which Strategies 2 and 3 outperforms "buy-and-hold" are highlighted in red).

Table 7. The optimal moving-window sizes of Strategy 2 for the 12 stocks (the red entries indicate that Strategy 2 beats "buy-and-hold", while the numbers in the brackets indicate the percentage profits)

\begin{tabular}{|c|c|c|c|c|}
\hline Transaction cost & buy-and-hold & Optimal strategy & $\begin{array}{l}\text { Optimal moving- } \\
\text { window size }\end{array}$ & $\begin{array}{l}\text { No. of times of buying } \\
\text { (or selling) the stock for } \\
\text { the optimal strategy }\end{array}$ \\
\hline \multicolumn{5}{|c|}{ Stock no. 5} \\
\hline $0 \%$ & $\begin{array}{c}-54.91 \\
(-44.59 \%)\end{array}$ & $\begin{array}{c}12.96 \\
(10.53 \%)\end{array}$ & 194 & 12 \\
\hline $0.1 \%$ & $\begin{array}{c}-55.10 \\
(-44.70 \%)\end{array}$ & $\begin{array}{c}9.99 \\
(8.11 \%)\end{array}$ & 194 & 12 \\
\hline $0.2 \%$ & $\begin{array}{c}-55.29 \\
(-44.81 \%)\end{array}$ & $\begin{array}{c}7.03 \\
(5.69 \%)\end{array}$ & 194 & 12 \\
\hline $0.35 \%$ & $\begin{array}{c}-55.58 \\
(-44.97 \%)\end{array}$ & $\begin{array}{c}2.57 \\
(2.08 \%)\end{array}$ & 194 & 12 \\
\hline \multicolumn{5}{|c|}{ Stock no. 12} \\
\hline $0 \%$ & $\begin{array}{c}-8.79 \\
(-28.96 \%)\end{array}$ & $\begin{array}{c}12.25 \\
(47.66 \%)\end{array}$ & 225 & 11 \\
\hline $0.1 \%$ & $\begin{array}{c}-8.84 \\
(-29.10 \%)\end{array}$ & $\begin{array}{c}11.52 \\
(44.78 \%) \\
\end{array}$ & 225 & 11 \\
\hline $0.2 \%$ & $\begin{array}{c}-8.89 \\
(-29.24 \%)\end{array}$ & $\begin{array}{c}10.79 \\
(41.90 \%)\end{array}$ & 225 & 11 \\
\hline $0.35 \%$ & $\begin{array}{c}-8.97 \\
(-29.45 \%)\end{array}$ & $\begin{array}{c}9.70 \\
(37.60 \%)\end{array}$ & 225 & 11 \\
\hline \multicolumn{5}{|c|}{ Stock no. 16} \\
\hline $0 \%$ & $\begin{array}{c}-13.15 \\
(-16.91 \%)\end{array}$ & $\begin{array}{c}64.20 \\
(82.57 \%)\end{array}$ & 66 & 12 \\
\hline $0.1 \%$ & $\begin{array}{c}-13.29 \\
(-17.08 \%)\end{array}$ & $\begin{array}{c}62.14 \\
(79.85 \%)\end{array}$ & 66 & 12 \\
\hline $0.2 \%$ & $\begin{array}{c}-13.43 \\
(-17.24 \%)\end{array}$ & $\begin{array}{c}60.09 \\
(77.13 \%)\end{array}$ & 66 & 12 \\
\hline $0.35 \%$ & $\begin{array}{c}-13.65 \\
(-17.49 \%)\end{array}$ & $\begin{array}{c}57.01 \\
(73.06 \%)\end{array}$ & 66 & 12 \\
\hline
\end{tabular}


Continue of Table 7

\begin{tabular}{|c|c|c|c|c|}
\hline Transaction cost & buy-and-hold & Optimal strategy & $\begin{array}{l}\text { Optimal moving- } \\
\text { window size }\end{array}$ & $\begin{array}{l}\text { No. of times of buying } \\
\text { (or selling) the stock for } \\
\text { the optimal strategy }\end{array}$ \\
\hline \multicolumn{5}{|c|}{ Stock no. 83} \\
\hline $0 \%$ & $\begin{array}{c}0.34 \\
(4.83 \%)\end{array}$ & $\begin{array}{c}11.32 \\
(162.82 \%)\end{array}$ & 106 & 14 \\
\hline $0.1 \%$ & $\begin{array}{c}0.32 \\
(4.62 \%)\end{array}$ & $\begin{array}{c}11.03 \\
(158.37 \%)\end{array}$ & 106 & 14 \\
\hline $0.2 \%$ & $\begin{array}{c}0.31 \\
(4.41 \%) \\
\end{array}$ & $\begin{array}{c}10.79 \\
(154.90 \%) \\
\end{array}$ & 104 & 11 \\
\hline $0.35 \%$ & $\begin{array}{c}0.29 \\
(4.10 \%) \\
\end{array}$ & $\begin{array}{c}10.45 \\
(149.73 \%) \\
\end{array}$ & 104 & 11 \\
\hline \multicolumn{5}{|c|}{ Stock no. 101} \\
\hline $0 \%$ & $\begin{array}{c}4.84 \\
(40.33 \%) \\
\end{array}$ & $\begin{array}{c}14.85 \\
(123.75 \%)\end{array}$ & 170 & 11 \\
\hline $0.1 \%$ & $\begin{array}{c}4.81 \\
(40.05 \%) \\
\end{array}$ & $\begin{array}{c}14.46 \\
(120.41 \%)\end{array}$ & 170 & 11 \\
\hline $0.2 \%$ & $\begin{array}{c}4.78 \\
(39.77 \%)\end{array}$ & $\begin{array}{c}14.08 \\
(117.08 \%)\end{array}$ & 170 & 11 \\
\hline $0.35 \%$ & $\begin{array}{c}4.74 \\
(39.35 \%) \\
\end{array}$ & $\begin{array}{c}13.50 \\
(112.10 \%) \\
\end{array}$ & 170 & 11 \\
\hline \multicolumn{5}{|c|}{ Stock no. 388} \\
\hline $0 \%$ & $\begin{array}{c}52.80 \\
(253.85 \%)\end{array}$ & $\begin{array}{c}211.55 \\
(1017.07 \%)\end{array}$ & 20 & 29 \\
\hline $0.1 \%$ & $\begin{array}{c}52.71 \\
(253.14 \%)\end{array}$ & $\begin{array}{c}207.23 \\
(995.32 \%)\end{array}$ & 20 & 29 \\
\hline $0.2 \%$ & $\begin{array}{c}52.61 \\
(252.43 \%)\end{array}$ & $\begin{array}{c}202.92 \\
(973.62 \%)\end{array}$ & 20 & 29 \\
\hline $0.35 \%$ & $\begin{array}{c}52.47 \\
(251.38 \%)\end{array}$ & $\begin{array}{c}196.44 \\
(941.15 \%)\end{array}$ & 20 & 29 \\
\hline \multicolumn{5}{|c|}{ Stock no. 688} \\
\hline $0 \%$ & $\begin{array}{c}8.86 \\
(494.03 \%) \\
\end{array}$ & $\begin{array}{c}13.39 \\
(746.79 \%) \\
\end{array}$ & 121 & 11 \\
\hline $0.1 \%$ & $\begin{array}{c}8.85 \\
(492.85 \%) \\
\end{array}$ & $\begin{array}{c}13.24 \\
(737.81 \%)\end{array}$ & 121 & 11 \\
\hline $0.2 \%$ & $\begin{array}{c}8.83 \\
(491.66 \%) \\
\end{array}$ & $\begin{array}{c}13.09 \\
(728.85 \%)\end{array}$ & 121 & 11 \\
\hline $0.35 \%$ & $\begin{array}{c}8.81 \\
(489.89 \%) \\
\end{array}$ & $\begin{array}{c}12.87 \\
(715.44 \%) \\
\end{array}$ & 121 & 11 \\
\hline \multicolumn{5}{|c|}{ Stock no. 857} \\
\hline $0 \%$ & $\begin{array}{c}2.64 \\
(63.61 \%) \\
\end{array}$ & $\begin{array}{c}7.56 \\
(182.17 \%) \\
\end{array}$ & 128 & 10 \\
\hline $0.1 \%$ & $\begin{array}{c}2.63 \\
(63.29 \%) \\
\end{array}$ & $\begin{array}{c}7.37 \\
(177.30 \%) \\
\end{array}$ & 128 & 10 \\
\hline $0.2 \%$ & $\begin{array}{c}2.62 \\
(62.96 \%) \\
\end{array}$ & $\begin{array}{c}7.17 \\
(172.45 \%) \\
\end{array}$ & 128 & 10 \\
\hline $0.35 \%$ & $\begin{array}{c}2.60 \\
(62.47 \%) \\
\end{array}$ & $\begin{array}{c}6.88 \\
(165.18 \%) \\
\end{array}$ & 128 & 10 \\
\hline \multicolumn{5}{|c|}{ Stock no. 883} \\
\hline $0 \%$ & $\begin{array}{c}3.07 \\
(73.41 \%)\end{array}$ & $\begin{array}{c}8.21 \\
(196.53 \%)\end{array}$ & 161 & 15 \\
\hline $0.1 \%$ & $\begin{array}{c}3.05 \\
(73.07 \%) \\
\end{array}$ & $\begin{array}{c}7.98 \\
(190.92 \%)\end{array}$ & 161 & 15 \\
\hline $0.2 \%$ & $\begin{array}{c}3.04 \\
(72.72 \%)\end{array}$ & $\begin{array}{c}7.75 \\
(185.33 \%) \\
\end{array}$ & 161 & 15 \\
\hline $0.35 \%$ & $\begin{array}{c}3.03 \\
(72.20 \%) \\
\end{array}$ & $\begin{array}{c}7.41 \\
(176.96 \%) \\
\end{array}$ & 161 & 15 \\
\hline \multicolumn{5}{|c|}{ Stock no. 941} \\
\hline $0 \%$ & $\begin{array}{c}51.45 \\
(195.26 \%)\end{array}$ & $\begin{array}{c}109.10 \\
(414.04 \%)\end{array}$ & 145 & 2 \\
\hline $0.1 \%$ & $\begin{array}{c}51.35 \\
(194.67 \%)\end{array}$ & $\begin{array}{c}108.89 \\
(412.83 \%)\end{array}$ & 145 & 2 \\
\hline $0.2 \%$ & $\begin{array}{c}51.24 \\
(194.08 \%)\end{array}$ & $\begin{array}{c}108.68 \\
(411.62 \%)\end{array}$ & 145 & 2 \\
\hline $0.35 \%$ & $\begin{array}{c}51.09 \\
(193.20 \%) \\
\end{array}$ & $\begin{array}{c}108.37 \\
(409.82 \%) \\
\end{array}$ & 145 & 2 \\
\hline \multicolumn{5}{|c|}{ Stock no. 1109} \\
\hline $0 \%$ & $\begin{array}{c}8.18 \\
(619.70 \%)\end{array}$ & $\begin{array}{c}12.10 \\
(916.29 \%)\end{array}$ & 119 & 15 \\
\hline
\end{tabular}


End of Table 7

\begin{tabular}{|c|c|c|c|c|}
\hline Transaction cost & buy-and-hold & Optimal strategy & $\begin{array}{l}\text { Optimal moving- } \\
\text { window size }\end{array}$ & $\begin{array}{l}\text { No. of times of buying } \\
\text { (or selling) the stock for } \\
\text { the optimal strategy }\end{array}$ \\
\hline $0.1 \%$ & $\begin{array}{c}8.17 \\
(618.26 \%) \\
\end{array}$ & $\begin{array}{c}11.92 \\
(901.87 \%) \\
\end{array}$ & 119 & 15 \\
\hline $0.2 \%$ & $\begin{array}{c}8.16 \\
(616.82 \%) \\
\end{array}$ & $\begin{array}{c}11.74 \\
(887.48 \%) \\
\end{array}$ & 119 & 15 \\
\hline $0.35 \%$ & $\begin{array}{c}8.14 \\
(614.68 \%) \\
\end{array}$ & $\begin{array}{c}11.47 \\
(865.94 \%) \\
\end{array}$ & 119 & 15 \\
\hline \multicolumn{5}{|c|}{ Stock no. 2628} \\
\hline $0 \%$ & $\begin{array}{c}18.35 \\
(352.88 \%) \\
\end{array}$ & $\begin{array}{c}30.95 \\
(595.19 \%) \\
\end{array}$ & 82 & 18 \\
\hline $0.1 \%$ & $\begin{array}{c}18.32 \\
(351.98 \%)\end{array}$ & $\begin{array}{c}30.39 \\
(583.88 \%)\end{array}$ & 82 & 18 \\
\hline $0.2 \%$ & $\begin{array}{c}18.29 \\
(351.08 \%)\end{array}$ & $\begin{array}{c}29.83 \\
(572.60 \%) \\
\end{array}$ & 82 & 18 \\
\hline $0.35 \%$ & $\begin{array}{c}18.25 \\
(349.73 \%)\end{array}$ & $\begin{array}{c}29.00 \\
(555.71 \%)\end{array}$ & 82 & 18 \\
\hline
\end{tabular}

Table 8. The optimal moving-window sizes of Strategy 3 for the 12 stocks (the red entries indicate that Strategy 3 beats "buy-and-hold", while the numbers in the brackets indicate the percentage profits)

\begin{tabular}{|c|c|c|c|c|}
\hline Transaction cost & buy-and-hold & Optimal strategy & $\begin{array}{l}\text { Optimal moving- } \\
\text { window size }\end{array}$ & $\begin{array}{l}\text { No. of times of buying } \\
\text { (or selling) the stock for } \\
\text { the optimal strategy }\end{array}$ \\
\hline \multicolumn{5}{|c|}{ Stock no. 5} \\
\hline $0 \%$ & $\begin{array}{c}-41.86 \\
(-33.99 \%) \\
\end{array}$ & $\begin{array}{c}29.18 \\
(23.69 \%) \\
\end{array}$ & 77 & 40 \\
\hline $0.1 \%$ & $\begin{array}{c}-42.06 \\
(-34.12 \%) \\
\end{array}$ & $\begin{array}{c}21.33 \\
(17.30 \%)\end{array}$ & 77 & 40 \\
\hline $0.2 \%$ & $\begin{array}{c}-42.27 \\
(-34.25 \%) \\
\end{array}$ & $\begin{array}{c}13.47 \\
(10.92 \%)\end{array}$ & 77 & 40 \\
\hline $0.35 \%$ & $\begin{array}{c}-42.57 \\
(-34.45 \%)\end{array}$ & $\begin{array}{c}1.69 \\
(1.37 \%)\end{array}$ & 77 & 40 \\
\hline \multicolumn{5}{|c|}{ Stock no. 12} \\
\hline $0 \%$ & $\begin{array}{c}10.74 \\
(35.40 \%) \\
\end{array}$ & $\begin{array}{c}29.75 \\
(98.03 \%) \\
\end{array}$ & 60 & 48 \\
\hline $0.1 \%$ & $\begin{array}{c}10.67 \\
(35.13 \%)\end{array}$ & $\begin{array}{c}26.56 \\
(87.41 \%) \\
\end{array}$ & 60 & 48 \\
\hline $0.2 \%$ & $\begin{array}{c}10.60 \\
(34.86 \%)\end{array}$ & $\begin{array}{c}23.36 \\
(76.81 \%)\end{array}$ & 60 & 48 \\
\hline $0.35 \%$ & $\begin{array}{c}10.49 \\
(34.45 \%) \\
\end{array}$ & $\begin{array}{c}18.57 \\
(60.96 \%) \\
\end{array}$ & 60 & 48 \\
\hline \multicolumn{5}{|c|}{ Stock no. 16} \\
\hline $0 \%$ & $\begin{array}{c}38.45 \\
(49.45 \%)\end{array}$ & $\begin{array}{c}120.95 \\
(155.56 \%) \\
\end{array}$ & 82 & 44 \\
\hline $0.1 \%$ & $\begin{array}{c}38.26 \\
(49.15 \%)\end{array}$ & $\begin{array}{c}112.25 \\
(144.23 \%)\end{array}$ & 82 & 44 \\
\hline $0.2 \%$ & $\begin{array}{c}38.06 \\
(48.86 \%)\end{array}$ & $\begin{array}{c}103.55 \\
(132.91 \%) \\
\end{array}$ & 82 & 44 \\
\hline $0.35 \%$ & $\begin{array}{c}37.77 \\
(48.41 \%)\end{array}$ & $\begin{array}{c}90.49 \\
(115.98 \%) \\
\end{array}$ & 82 & 44 \\
\hline \multicolumn{5}{|c|}{ Stock no. 83} \\
\hline $0 \%$ & $\begin{array}{c}6.99 \\
(100.43 \%) \\
\end{array}$ & $\begin{array}{c}15.59 \\
(224.17 \%) \\
\end{array}$ & 64 & 51 \\
\hline $0.1 \%$ & $\begin{array}{c}6.96 \\
(100.03 \%) \\
\end{array}$ & $\begin{array}{c}14.43 \\
(207.21 \%) \\
\end{array}$ & 64 & 51 \\
\hline $0.2 \%$ & $\begin{array}{c}6.94 \\
(99.63 \%) \\
\end{array}$ & $\begin{array}{c}13.26 \\
(190.29 \%) \\
\end{array}$ & 64 & 51 \\
\hline $0.35 \%$ & $\begin{array}{c}6.91 \\
(99.03 \%) \\
\end{array}$ & $\begin{array}{c}11.51 \\
(164.96 \%) \\
\end{array}$ & 64 & 51 \\
\hline \multicolumn{5}{|c|}{ Stock no. 101} \\
\hline $0 \%$ & $\begin{array}{c}18.80 \\
(156.67 \%) \\
\end{array}$ & $\begin{array}{c}29.98 \\
(249.83 \%) \\
\end{array}$ & 123 & 38 \\
\hline $0.1 \%$ & $\begin{array}{c}18.76 \\
(156.15 \%) \\
\end{array}$ & $\begin{array}{c}28.37 \\
(236.16 \%) \\
\end{array}$ & 123 & 38 \\
\hline $0.2 \%$ & $\begin{array}{c}18.71 \\
(155.64 \%)\end{array}$ & $\begin{array}{c}26.76 \\
(222.52 \%)\end{array}$ & 123 & 38 \\
\hline
\end{tabular}


End of Table 8

\begin{tabular}{|c|c|c|c|c|}
\hline Transaction cost & buy-and-hold & Optimal strategy & $\begin{array}{l}\text { Optimal moving- } \\
\text { window size }\end{array}$ & $\begin{array}{l}\text { No. of times of buying } \\
\text { (or selling) the stock for } \\
\text { the optimal strategy }\end{array}$ \\
\hline $0.35 \%$ & $\begin{array}{c}18.65 \\
(154.88 \%) \\
\end{array}$ & $\begin{array}{c}24.34 \\
(202.11 \%) \\
\end{array}$ & 123 & 38 \\
\hline \multicolumn{5}{|c|}{ Stock no. 388} \\
\hline $0 \%$ & $\begin{array}{c}111.10 \\
(534.13 \%)\end{array}$ & $\begin{array}{c}288.30 \\
(1386.06 \%)\end{array}$ & 80 & 22 \\
\hline $0.1 \%$ & $\begin{array}{c}110.95 \\
(532.87 \%)\end{array}$ & $\begin{array}{c}283.52 \\
(1361.72 \%) \\
\end{array}$ & 80 & 22 \\
\hline $0.2 \%$ & $\begin{array}{c}110.79 \\
(531.60 \%)\end{array}$ & $\begin{array}{c}278.74 \\
(1337.43 \%)\end{array}$ & 80 & 22 \\
\hline $0.35 \%$ & $\begin{array}{c}110.57 \\
(529.71 \%) \\
\end{array}$ & $\begin{array}{c}271.57 \\
(1301.09 \%) \\
\end{array}$ & 80 & 22 \\
\hline \multicolumn{5}{|c|}{ Stock no. 688} \\
\hline $0 \%$ & $\begin{array}{c}21.03 \\
(1172.95 \%) \\
\end{array}$ & $\begin{array}{c}20.61 \\
(1149.47 \%) \\
\end{array}$ & 113 & 35 \\
\hline $0.1 \%$ & $\begin{array}{c}21.01 \\
(1170.41 \%) \\
\end{array}$ & $\begin{array}{c}19.76 \\
(1100.98 \%)\end{array}$ & 113 & 35 \\
\hline $0.2 \%$ & $\begin{array}{c}20.98 \\
(1167.87 \%)\end{array}$ & $\begin{array}{c}18.91 \\
(1052.59 \%)\end{array}$ & 113 & 35 \\
\hline $0.35 \%$ & $\begin{array}{c}20.94 \\
(1164.07 \%)\end{array}$ & $\begin{array}{c}17.64 \\
(980.18 \%)\end{array}$ & 113 & 35 \\
\hline \multicolumn{5}{|c|}{ Stock no. 857} \\
\hline $0 \%$ & $\begin{array}{c}6.83 \\
(164.58 \%)\end{array}$ & $\begin{array}{c}8.01 \\
(193.01 \%)\end{array}$ & 120 & 33 \\
\hline $0.1 \%$ & $\begin{array}{c}6.81 \\
(164.05 \%)\end{array}$ & $\begin{array}{c}7.36 \\
(177.19 \%)\end{array}$ & 120 & 33 \\
\hline $0.2 \%$ & $\begin{array}{c}6.80 \\
(163.52 \%)\end{array}$ & $\begin{array}{c}6.71 \\
(161.40 \%)\end{array}$ & 120 & 33 \\
\hline $0.35 \%$ & $\begin{array}{c}6.78 \\
(162.73 \%)\end{array}$ & $\begin{array}{c}5.74 \\
(137.78 \%)\end{array}$ & 120 & 33 \\
\hline \multicolumn{5}{|c|}{ Stock no. 883} \\
\hline $0 \%$ & $\begin{array}{c}12.61 \\
(301.92 \%)\end{array}$ & $\begin{array}{c}15.86 \\
(379.76 \%) \\
\end{array}$ & 199 & 15 \\
\hline $0.1 \%$ & $\begin{array}{c}12.58 \\
(301.11 \%)\end{array}$ & $\begin{array}{c}15.58 \\
(372.75 \%)\end{array}$ & 199 & 15 \\
\hline $0.2 \%$ & $\begin{array}{c}12.56 \\
(300.31 \%)\end{array}$ & $\begin{array}{c}15.30 \\
(365.76 \%)\end{array}$ & 199 & 15 \\
\hline $0.35 \%$ & $\begin{array}{c}12.53 \\
(299.11 \%)\end{array}$ & $\begin{array}{c}14.89 \\
(355.29 \%)\end{array}$ & 199 & 15 \\
\hline \multicolumn{5}{|c|}{ Stock no. 941} \\
\hline $0 \%$ & $\begin{array}{c}63.90 \\
(242.50 \%) \\
\end{array}$ & $\begin{array}{c}94.55 \\
(358.82 \%) \\
\end{array}$ & 140 & 40 \\
\hline $0.1 \%$ & $\begin{array}{c}63.78 \\
(241.82 \%)\end{array}$ & $\begin{array}{c}88.38 \\
(335.07 \%)\end{array}$ & 140 & 40 \\
\hline $0.2 \%$ & $\begin{array}{c}63.67 \\
(241.14 \%)\end{array}$ & $\begin{array}{c}82.21 \\
(311.36 \%)\end{array}$ & 140 & 40 \\
\hline $0.35 \%$ & $\begin{array}{c}63.49 \\
(240.12 \%)\end{array}$ & $\begin{array}{c}72.95 \\
(275.89 \%)\end{array}$ & 140 & 40 \\
\hline \multicolumn{5}{|c|}{ Stock no. 1109} \\
\hline $0 \%$ & $\begin{array}{c}19.78 \\
(1498.48 \%)\end{array}$ & $\begin{array}{c}23.47 \\
(1778.03 \%)\end{array}$ & 146 & 32 \\
\hline $0.1 \%$ & $\begin{array}{c}19.76 \\
(1495.29 \%)\end{array}$ & $\begin{array}{c}22.78 \\
(1724.24 \%) \\
\end{array}$ & 146 & 32 \\
\hline $0.2 \%$ & $\begin{array}{c}19.74 \\
(1492.10 \%)\end{array}$ & $\begin{array}{c}22.10 \\
(1670.56 \%)\end{array}$ & 146 & 32 \\
\hline $0.35 \%$ & $\begin{array}{c}19.70 \\
(1487.33 \%)\end{array}$ & $\begin{array}{c}21.06 \\
(1590.24 \%)\end{array}$ & 146 & 32 \\
\hline \multicolumn{5}{|c|}{ Stock no. 2628} \\
\hline $0 \%$ & $\begin{array}{c}20.10 \\
(386.54 \%)\end{array}$ & $\begin{array}{c}42.23 \\
(812.12 \%)\end{array}$ & 80 & 41 \\
\hline $0.1 \%$ & $\begin{array}{c}20.07 \\
(385.57 \%)\end{array}$ & $\begin{array}{c}40.52 \\
(778.52 \%)\end{array}$ & 80 & 41 \\
\hline $0.2 \%$ & $\begin{array}{c}20.04 \\
(384.60 \%)\end{array}$ & $\begin{array}{c}38.82 \\
(744.99 \%)\end{array}$ & 80 & 41 \\
\hline $0.35 \%$ & $\begin{array}{c}19.99 \\
(383.14 \%)\end{array}$ & $\begin{array}{c}36.26 \\
(694.82 \%)\end{array}$ & 80 & 41 \\
\hline
\end{tabular}


From Tables 7 and 8, when the optimal moving-window size is used, Strategy 2 outperforms "buy-and-hold" for all cases, while Strategy 3 beats "buy-and-hold" for all cases except for stock no. 688. However, for each stock, the optimal moving-window sizes of the two strategies are different. In particular, the optimal moving-window sizes of Strategies 1 and 2 are totally different for all stocks, no matter how much the transaction cost is. However, the optimal moving-window size of Strategies 1 and 3 are the same for some stocks (stocks no. 5, 16, $883(0.2 \%$ and $0.35 \%$ transaction costs) and 941 ( $0.35 \%$ transaction costs)). This is because Strategy 3 covers a longer length of period than Strategy 2 does, so there is a higher chance that the optimal moving-window size for Strategy 3 is the same as that for Strategy 1.

\section{Conclusions}

In this study, we apply Hui and Chan (2018)'s generalized time-dependent trading strategy on 12 Hong Kong listed stocks during three different periods:

a) December 31, 2004 - January 29, 2016

b) December 31, 2004 - December 31, 2008

c) December 31, 2004 - December 31, 2012

The main results are listed as follows:

1) Strategy 2 outperforms "buy-and-hold" overwhelmingly, but Strategy 3 generally underperforms "buyand-hold", reflecting that our strategy is more effective during bear markets than during bull markets.

2) Our strategies are more effective on stocks of nonChina enterprises than on stocks of China enterprises in general.

3) The optimal moving-window sizes of Strategy 2 are different from those of Strategy 1 for all stocks, but the optimal moving-window sizes of Strategy 3 are same as those of Strategy 1 for some stocks.

The results show that whether our strategies outperforms "buy-and-hold" or not depends significantly on the trend of the stock during the period. As explained in Section 5, our strategies are more effective during bear markets than during bull markets. Furthermore, the market condition is always changing. The stock prices rise during some times, but fall during other times, so changing the period of observation may affect the excess profit of our strategies over "buy-and-hold". Therefore, choosing the right period of time is important when one would like to apply our strategies. This can help investors to earn more profits in their investment. This is not only applicable to equity investment, but is also applicable to property investment, too. However, the frequencies of most real estate indices are either weekly or monthly, which are much lower than the frequency of equities, which is daily. Therefore, when applying our strategy to investment in actual real estate, a smaller moving-window size should be used in order to avoid lagging behind too much. Nevertheless, the general rule is still to follow our strategy during bear markets, but to adhere to "buy-and-hold" during bull markets. This is useful for property practitioners to have a better strategic property management in order to increase the value of their portfolio.

\section{Acknowledgement}

We are grateful for the financial support from the PolyU Internal Research Grant (Project \# G-YBJL) and GRF (Project \# B-Q42Q (PolyU 15 205 9/14E)).

\section{References}

Agyei-Ampomah, S. (2011). Stock market integration in Africa. Managerial Finance, 37, 242-256.

https://doi.org/10.1108/03074351111113306

Ambrose, B. W., \& Diop, M. (2014). Spillover effects of subprime mortgage originations: the effects of single-family mortgage credit expansion on the multifamily rental market. Journal of Urban Economics, 81, 114-135. https://doi.org/10.1016/j.jue.2014.03.005

Barber, B. M., \& Odean, T. (2000). Trading is hazardous to your wealth: the common stock investment performance of individual investors. Journal of Finance, 55(2), 773-806. https://doi.org/10.1111/0022-1082.00226

Basse, T., Kruse, R., \& Wegener, C. (2017). The walking debt crisis (No. 2017-06). Department of Economics and Business Economics, Aarhus University.

Bekaert, G., Ehrmann, M., Fratzscher, M., \& Mehl, A. (2014). The global crisis and equity market contagion. Journal of Finance, 69(6), 2597-2649. https://doi.org/10.1111/jofi.12203

Cheng, P., Lin, Z., \& Liu, Y. (2010). Illiquidity, transaction cost, and optimal holding period for real estate: theory and application. Journal of Housing Economics, 19(2), 109-118.

Dai, M., Jin, H., Zhong, Y., \& Zhou, X. Y. (2008). Buy on the lows and sell on the highs. Working Paper, University of Oxford.

Deremble, C., Seager, P., Potters, M., \& Bouchaud, J. P. (2014). Two centuries of trend following. Retrieved from arXiv.org

Dooley, M., \& Hutchison, M. (2009). Transmission of the US subprime crisis to emerging markets: evidence on the decoupling-recoupling hypothesis. Journal of International Money and Finance, 28(8), 1331-1349.

https://doi.org/10.1016/j.jimonfin.2009.08.004

Du Toit, J., \& Peskir, G. (2008). Selling a stock at the ultimate maximum. Annals of Applied Probability, 19, 983-1014. https://doi.org/10.1214/08-AAP566

Gallo, J. G., Lockwood, L. J., \& Zhang, Y. (2013). Structuring global property portfolios: a cointegration approach. Journal of Real Estate Research, 35(1), 53-82.

Hatemi-J, A., Roca, E., \& Al-Shayeb, A. (2014). How integrated are real estate markets with the world market? Evidence from case-wise bootstrap analysis. Economic Modelling, 37, 137142. https://doi.org/10.1016/j.econmod.2013.10.037

Hui, E. C. M., \& Chan, K. K. K. (2014). Can we still beat "buyand-hold" for individual stocks?. Physica A: Statistical Mechanics and its Applications, 410, 513-534. https://doi.org/10.1016/j.physa.2014.05.061

Hui, E., \& Chan, K. (2018). A new time-dependent trading strategy for securitized real estate and equity indices. International Journal of Strategic Property Management, 22(1), 64-79. https://doi.org/10.3846/1648715X.2016.1260072

Hui, E. C. M., \& Chen, J. (2012). Investigating the change of causality in emerging property markets during the financial tsunami. Physica A: Statistical Mechanics and its Applications, 391(15), 3951-3962. https://doi.org/10.1016/j.physa.2012.03.007 
Hui, E. C. M., Wright, J. A., \& Yam, S. C. P. (2014a). Calendar effects and real estate securities. Journal of Real Estate Finance and Economics, 49(1), 91-115.

https://doi.org/10.1007/s11146-012-9398-4

Hui, E. C. M., \& Yam, S. C. P. (2014). Can we beat the "buyand-hold" strategy? Analysis on European and American securitized real estate indices. International Journal of Strategic Property Management, 18(1), 28-37. https://doi.org/10.3846/1648715X.2013.862190

Hui, E. C. M., Yam, S. C. P, Wright, J., \& Chan, K. K. K. (2014b). Shall we buy and hold? Evidence from Asian real estate markets. Journal of Property Investment and Finance, 32(2), 168186. https://doi.org/10.1108/JPIF-09-2013-0059

Hui, E. C. M., Yam, S. C. P., \& Chen, S. W. (2012). Shiryaev-Zhou index - a noble approach to benchmarking and analysis of real estate stocks. International Journal of Strategic Property Management, 16(2), 158-172. https://doi.org/10.3846/1648715X.2011.638946

Kim, K. H., \& Renaud, B. (2009). The global house price boom and its unwinding: an analysis and a commentary. Housing Studies, 24(1), 7-24. https://doi.org/10.1080/02673030802550128

Krystalogianni, A. and Tsolacos, S. (2004). Regime switching in yield structures and real estate investment. Journal of Property Research, 21(4), 279-299. https://doi.org/10.1080/09599910500182108

Malkiel, B. G. (2003). The efficient market hypothesis and its critics. The Journal of Economic Perspectives, 17(1), 59-82. https://doi.org/10.1257/089533003321164958

Malkiel, B. G. (2005). Reflections on the efficient market hypothesis: 30 years later. Financial Review, 40(1), 1-9. https://doi.org/10.1111/j.0732-8516.2005.00090.x

Malkiel, B. G., \& Fama, E. F. (1970). Efficient capital markets: a review of theory and empirical work. Journal of Finance, 25(2), 383-417. https://doi.org/10.1111/j.1540-6261.1970.tb00518.x

Markowitz, H. M. (1952). Portfolio selection. Journal of Finance, $7(1), 77-91$.
Merton, R. C. (1971). Optimum consumption and portfolio rules in a continuous-time model. Journal of Economic Theory, 3, 373-413. https://doi.org/10.1016/0022-0531(71)90038-X

Mori, M., \& Ziobrowski, A. J. (2011). Performance of pairs trading strategy in the US REIT market. Real Estate Economics, 39(3), 409-428. https://doi.org/10.1111/j.1540-6229.2010.00302.x

New York Times. (2009). Poking holes in a theory on markets. Retrieved from http://www.nytimes.com/2009/06/06/ business $/ 06$ nocera.html? scp=1\&sq=efficient $\% 20$ market $\&$ st $=$ cse

Richardson, H. R. (1989). A minimum variance result in continuous trading portfolio optimization. Management Science, 35, 1045-1055. https://doi.org/10.1287/mnsc.35.9.1045

Samuelson, P. A. (1969). Lifetime portfolio selection by dynamic stochastic programming. Review of Economics and Statistics, 51, 239-246. https://doi.org/10.2307/1926559

Shiryaev, A. N., Xu, Z. Q., \& Zhou, X. Y. (2008). Thou shalt buy and hold. Quantitative Finance, 8(8), 765-776. https://doi.org/10.1080/14697680802563732

Volcker, P. (2011). Financial reform: unfinished business. New York Review of Books, November 24, 2011 Issue.

Wong, W. K., Wright, J. A., Yam, S. C. P., \& Yung, S. P. (2012). A mixed Sharpe ratio. Risk and Decision Analysis, 3, 37-65.

Yam, S. C. P., Yung, S. P., Zhou, W. (2012). A unified 'bang-bang' principle with respect to R-invariant performance benchmarks. Theory of Probability and Its Applications, 57(2), 405414. https://doi.org/10.4213/tvp4457

Yam, S. C. P., Yung, S. P. and Zhou, W. (2012a). Optimal selling time in stock market over a finite time horizon. Acta Mathematicae Applicatae Sinica, 28(3), 557-570. https://doi.org/10.1007/s10255-012-0169-Z

Yam, S. C. P., Yung, S. P. and Zhou, W. (2009). Two rationales behind the "buy-and-hold or sell-at-once" strategy. Journal of Applied Probability, 46, 651-668. https://doi.org/10.1239/jap/1253279844 